\title{
Losing Bargain: Why Winner-Take-All Vote Assignment is the Electoral College's Least Defensible Feature
}

Katherine Florey

Follow this and additional works at: https://scholarlycommons.law.case.edu/caselrev

Part of the Law Commons

\section{Recommended Citation}

Katherine Florey, Losing Bargain: Why Winner-Take-All Vote Assignment is the Electoral College's Least Defensible Feature, 68 Case W. Rsrv. L. Rev. 317 (2017)

Available at: https://scholarlycommons.law.case.edu/caselrev/vol68/iss2/4

This Article is brought to you for free and open access by the Student Journals at Case Western Reserve University School of Law Scholarly Commons. It has been accepted for inclusion in Case Western Reserve Law Review by an authorized administrator of Case Western Reserve University School of Law Scholarly Commons. 
Case Western Reserve Law Review · Volume $68 \cdot$ Issue $2 \cdot 2017$

\title{
LOSING BARGAIN: WHY WINNER-
}

\section{TAKe-All Vote Assignment is the \\ Electoral College's Least \\ DEFEnSIBLE FeATURE}

\author{
Katherine Florey
}

\begin{abstract}
The electoral college is usually considered as a single institution that - in contrast to a system of direct election - mediates the popular will and advances counter-majoritarian principles. To its critics, this role is a destructive one; the electoral college thwarts the foundational democratic idea that all votes should count equally and the majority's choice should lead. By contrast, defenders of the electoral college argue that it is a deliberately crafted institution whose deviations from nationwide popular sentiment are part of its design. Yet the electoral college is not a single institution but rather a combination of procedures. The electoral college produces results potentially different from those that would be achieved by direct election through several distinct mechanisms, including the two-vote bonus given to all states, the assignment of electoral votes based on total population rather than voters, and the award of state electoral votes on a winner-take-all basis. Of these mechanisms, the use of winner-take-all rules stands out as the least defensible. In contrast to other aspects of the electoral college, winner-take-all systems were not part of the electoral college's original design and were adopted haphazardly at the state level, without systematic consideration of their national consequences. Further, winnertake-all rules cause considerable harm by contributing most strongly to the risk of popular-electoral splits, by creating incentives for fraud, voter suppression, and other undesirable campaign tactics, and by arbitrarily privileging some voters' preferences at others' expense. As a result, advocates for electoral college reform should make abolition of winner-take-all central to both their critiques of the current process and their evaluation of reform proposals.
\end{abstract}

$\dagger \quad$ Professor of Law, University of California, Davis, School of Law. I wish to thank John Patrick Hunt, Derek T. Muller, Jae Ha, Aviva Simon, Kevin Johnson, and Madhavi Sunder for helpful contributions and support in writing this Article. 


\section{Contents}

INTRODUCTION 318

I. The Historical Development of Electoral College's

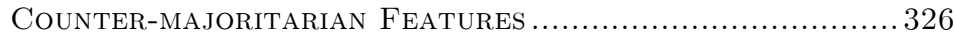

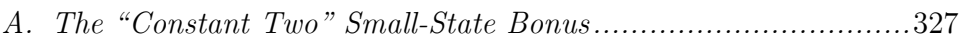

B. Population-Based Representation in the Electoral Vote .............331

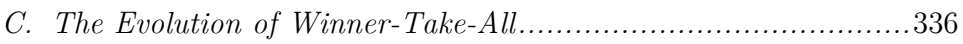

II. The Distinctive Ill Effects of Winner-Take-All ............ 345

A. Winner-Take-All's Negative Effects on the Election Process......345

1. Contributing to Arbitrary Electoral-Popular Splits ...............345

2. Incentives for Fraud and Voter Suppression..........................349

3. Arbitrarily Distributing Power to Certain Voter Groups .......352

4. Distortions of the Meaning of an Election ...........................356

5. Third-Party Mischief and Spoiler Effects...............................358

B. The Experience of Winner-Take-All in Party Nominations ........360

1. Winner-Take-All in the Evolution of Modern Primaries.........360

2. Conclusions from Winner-Take-All in Party Primaries ..........365

III. Implications for Electoral College Reform................... 366

A. The Underemphasis of Winner-Take-All in Electoral College Critiques ........................................................ 367

B. The Case That Winner-Take-All Is the Electoral College's Worst Feature .............................................................. 368

C. The Practical Consequences of a Winner-Take-All Focus ..........378

D. Reform Proposals and Winner-Take-All........................380

1. Direct Election: Proposals and Historical Experience .............381

2. Alternatives to Direct Election Proposals ...............................384

3. Using the Courts to Undermine Winner-Take-All ..................392

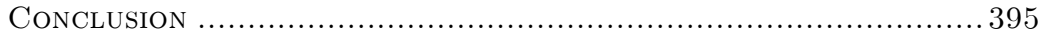

\section{INTRODUCTION}

Even as the electoral college has, for the second time in sixteen years, produced a president who did not win the popular vote, ${ }^{1}$ electoral college reform seems in some ways farther away than ever. No recent effort to change the manner in which the president is elected has progressed nearly as far as the proposed Bayh-Celler constitutional amendment to institute a direct election system, which passed the House by a wide margin in 1969 but ultimately failed to come to a vote in the Senate. ${ }^{2}$ While the National Popular Vote Interstate Compact-an

1. See infra notes 169-70 (discussing the election of George W. Bush in 2000 and Donald Trump in 2016).

2. See Lawrence D. Longley \& Alan G. Braun, The Politics of Electoral College Reform 139-78 (1972). 
ingenious idea developed by a group of professors and legislators in the wake of the 2000 election $^{3}$ - has been passed by eleven states, its progress has slowed with no state enacting it into law since New York did so in 2014. ${ }^{4}$ The current president of the United States, who in 2012 called the electoral college a "disaster for democracy," has more recently hailed it as "actually genius in that it brings all states, including the smaller ones, into play." ${ }^{5}$ Despite dire warnings in the decades prior to the 2000 election that an electoral-popular vote split would be a "debacle" and a "disaster," it seems that Americans have, in fact, learned to live with such a result as a regular occurrence. Indeed, not only have fears that an electoral-popular split would provoke a constitutional crisis failed to materialize, but the country's apparent acquiescence may even have decreased momentum for a change in the process. $^{7}$

Despite this discouraging backdrop, this Article argues that it is time to take up the discussion again from a new angle. The electoral college is usually considered as a single institution that - in contrast to a system of direct election-mediates the popular will and advances values other than those that would be served by pure direct democracy. To its critics, this role is a destructive one; the electoral college thwarts the foundational democratic principle that all votes should count equal-

3. John R. Koza et al., Every Vote Equal: A State-Based Plan for Electing the President By National Popular Vote 281-83 (4th ed. 2013).

4. See Status of National Popular Vote Bill in Each State, NAT'L Popular VoTE, http://www.nationalpopularvote.com/state-status [https://perma. cc/BR6D-6T76] (last visited Sept. 26, 2017). New York originally signed onto the compact for a limited time, but made its approval permanent in 2016. See New York, NAT'L Popular Vote, http://www.national popularvote.com/state/ny [https://perma.cc/76RM-KA3D] (last visited Sept. 26, 2017).

5. Glenn Kessler, Trump's Flip-Flop on the Electoral College: From 'Disaster' to 'Genius', Wash. Post (Nov. 15, 2016), https://www.washingtonpost. com/news/factchecker/wp/2016/11/15/trumps-flip-flop-on-the-electoral-colle ge-from-disaster-to-genius/?utm_term=.fb2040100ad9 [https://perma.cc/J7Z D-RQNT].

6. David W. Abbott \& James P. Levine, Wrong Winner: The Coming Debacle in the Electoral College 1 (1991).

7. Ann Althouse, for example, suggests that the failure of the widely predicted outrage to materialize following the 2000 presidential election's electoralpopular split reflects the belief that "[t]he numbers that show[] up in the popular vote tally [are] . . a arbitrary to some unknown degree" and winning the popular vote thus has less "moral sway" than earlier commentators had expected. Ann Althouse, Electoral College Reform: Déjà Vu, 95 Nw. U.L. REV. 993, 1012 (2001) (book review). 
ly and the majority's choice should lead. ${ }^{8}$ By contrast, the defenders of the electoral college argue that it is a deliberately crafted institution whose deviations from nationwide popular sentiment are part of its design. ${ }^{9}$

Yet the electoral college is not a single institution but rather a combination of procedures. The electoral college produces results potentially different from those that would be achieved by direct election through several distinct mechanisms, ${ }^{10}$ three of which are currently significant and relevant. ${ }^{11}$ First and most obviously, the electoral

8. See, for example, KozA ET AL., supra note 3, for an exhaustive defense of this proposition.

9. See, e.g., Tara Ross, Enlightened Democracy: The Case for the Electoral College 40 (2004) (arguing that the electoral college is one of several devices crafted by the Framers to balance majority will against protections for minorities); Judith Best, The Case Against Direct Election of the President: A Defense of the Electoral College 216 (1975) (asserting that the electoral college is part of our "Madisonian system of concurrent majorities designed to check majority factions that lead to majority tyranny").

10. See Althouse, supra note 7, at 996-97 (noting that 1960s reformers identified five distinct "areas of concern," similar to those discussed here, about the electoral college: the two bonus electoral votes awarded to each state; the "unit" or winner-take-all rule; the possibility of faithless electors; the House resolution mechanism; and the potential disparity between the popular and electoral vote).

11. See Lawrence D. Longley \& Neal R. Peirce, The Electoral College Primer 128 (1996) (describing these elements as potential causes of a popular-electoral vote split). In theory, and by its original design, the electoral college includes other mechanisms by which it could produce a result contrary to the popular vote outcome. First, state legislatures have great constitutional latitude to choose the method of appointing electors, allowing a state either to select pre-committed electors without regard to the popular vote or to appoint electors who would have the power to deviate from it. See U.S Const., art. II, § 1 (providing that electors may be appointed "in such Manner as the Legislature thereof may direct"). Second, the Twelfth Amendment allows the House of Representatives to resolve elections in which no candidate has an electoral majority. See U.S ConsT. amend. XII. Because the first mechanism has never been consequential in the outcome of an election and the second has not in the post-1824 era of modern parties, they are not clearly relevant to the current electoral process and this Article will not address them in detail. Nonetheless, it is worth noting that many past calls for electoral college reform have focused on these devices, particularly the threat of "faithless electors" who fail to honor the voters' choice in a particular state. See, e.g., LONGLEY \& BRAUn, supra note 2 , at 18 " "The problem of the faithless elector is neither theoretical nor unimportant."). Fears about faithless electors, however, may wane in the aftermath of the 2016 electoral process - only seven electors defected from their state's choice despite calls by many prominent figures for them to do so based on the popular-electoral vote split and the alleged unfitness of Donald Trump for the presidency. See Kyle Cheney, Lessig, Lawyers to Offer 
college gives a two-vote non-population-based bonus to each state, sometimes called the "constant two", ${ }^{12}$ thus relatively advantaging smaller states at the expense of larger ones. Many critics - and, in some cases, defenders - of the electoral college have tended to focus primarily on this feature, presumably because the manner in which it advantages small states' voters is readily apparent. Nonetheless, there is wide consensus that the two-vote bonus plays a relatively small role in the electoral college's operation. ${ }^{13}$

Second, the electoral college allocates power among states based on total population rather than voters, allowing groups such as nonvoters, children, noncitizens, and disenfranchised felons to count in the determination of each state's relative share of the electoral vote. ${ }^{14}$ By contrast, a system for direct election of the president would by definition only count those who are eligible to vote and who actually do so. This feature of the electoral college is not currently among its most controversial and, unlike the two-vote bonus, it need not necessarily be seen as undemocratic, particularly if one believes that the preferences of nonvoters are similar enough to those of voters to allow for a sort of virtual representation. After all, seats in the House of Representatives are apportioned the same way. ${ }^{15}$ Historically, however, the question whether to consider voting population or total population has been a major focus of dispute both in the initial design of the electoral college and in discussions about the future of apportionment following the Civil War. ${ }^{16}$

Finally-and with potentially momentous consequences - the electoral college overwhelmingly relies on a winner-take-all method of allocating state electoral votes, a system historically known as the "unit

Support to Anti-Trump Electors, Politico (Dec. 5, 2016), http://www. politico.com/story/2016/12/larry-lessig-electors-trump-232231 [https:// perma.cc/44RB-UFE9] (describing advocacy for anti-Trump votes by electors); 2016 Presidential Election Results, 270 TO WIN, http:// www.270towin.com/maps/2016-actual-electoral-map [https://perma.cc/B9 YE-B4PV] (noting that seven electors in total were "faithless" in the 2016 electoral vote, including two declining to vote for Trump).

12. See, e.g., Longley \& Braun, supra note 2, at 54 .

13. See Carleton W. Sterling, The Electoral College Biases Revealed: The Conventional Wisdom and Game Theory Models Notwithstanding, 31 W. POL. Q. 159, 170 (1978) ("The constant two factor is not the most important bias in the present system and has never been responsible for upsetting a popular vote favorite.").

14. See infra note 82 and accompanying text.

15. See U.S Const., art. I, § 2 .

16. See infra Part I.B (discussing the antebellum struggle in Congress to replace the three-fifths clause with a new method of apportionment). 
rule." ${ }^{17}$ Forty-eight states award electoral votes on a pure winner-takeall basis - the candidate who gets the most votes in that state receives the state's entire slate of electoral votes, regardless of margin of victory or overall percentage. Two states, Maine and Nebraska, use what might be called a modified winner-take-all system under which some electoral votes are awarded at large to the overall winner while others are awarded to the winner of each congressional district. ${ }^{18}$

In several important ways, the winner-take-all system differs sharply from the electoral college's other counter-majoritarian procedures. The first is the manner in which it came into being. In contrast to the two-vote bonus and population-based allocation, both of which were the subject of extensive historical debate and compromise ${ }^{19}$ the winner-take-all system evolved haphazardly at the state level, as a function of decisions by individual states designed to preserve their influence, rather than collective deliberation. ${ }^{20}$ Winner-take-all was not envisioned by the Framers, was in no way part of the electoral college's design, and has never been seriously addressed by Congress. ${ }^{21}$

Second, the winner-take-all system stands out for the force of its influence on results. Of the various electoral college mechanisms, winner-take-all has the greatest potential to produce a popular-electoral split on its own; it did so in the 2016 election, and it has been a significant and probably determinative factor in the popular-electoral splits of the past. ${ }^{22}$ In a large number of additional elections, winner-

17. See Longley \& Peirce, supra note 11, at 24-25.

18. See id. at 99 (describing Maine's arrangement, adopted in 1969, under which two votes are determined by district and two others at large, as well as Nebraska's allocation of three of its five votes by congressional district, adopted in 1992). Michigan briefly experimented with a similar system in the late 19th century, motivated by Democrats seeking to block the state's entire electoral slate from going to the Republican candidate. Id.

19. See infra Parts I.A-B.

20. See infra notes 96-107 and accompanying text.

21. The closest Congress has come to specifically considering the issue was in 1826, when Congress debated an amendment to select electors by congressional district. See generally Robert E. Ross, Federalism and the Electoral College: The Development of the General Ticket Method for Selecting Presidential Electors, 46 Publius: J. Federalism 147, 160-61 (2016). A district-based system, however, does not permit votes to have proportional weight and is not a true alternative to winner-take-all. See infra Part I.C (discussing the possibility that state level popular-electoral splits could occur under the district-based system).

22. There have been five elections in U.S. history-1824, 1876, 1888, 2000, and 2016 - in which the winner of the popular vote did not become president. The election of 1824, however, is generally not included with the others because approximately a quarter of the states did not allocate their votes through popular elections at the time. See BEST, supra note 9, at 25. 
take-all allocation came perilously close to creating such a split and would have done so with the shift of only a relative handful of votes. ${ }^{23}$ Further, even where it does not result in an ultimate victor different from the popular vote winner, the winner-take-all system frequently produces an electoral result seemingly at odds with the popular willmagnifying a popular plurality into a decisive win or converting a significant but hardly overwhelming victory into a landslide. ${ }^{24}$

Third, winner-take-all allocation has numerous pernicious effects on the electoral process in addition to its potential impact on outcome. As many observers have complained, the winner-take-all system causes candidates to focus resources and visits on a handful of close states, while slighting or completely ignoring the others. ${ }^{25}$ Perhaps more importantly, significant evidence suggests that non-swing states receive less attention from presidents while in office and that the concerns of swingstate voters disproportionately drive the national agenda. ${ }^{26}$ Winnertake-all also has a variety of negative effects on the electoral process itself. It effectively deprives consistent political minorities within a state of any representation in the presidential election. ${ }^{27}$ It arbitrarily makes residents of some states disproportionately influential by giving their

Likewise, the rampant fraud and voter suppression that plagued the 1876 election has led some commentators to regard the results in that race as suspect; that said, the winner-take-all feature of the electoral college played a substantial role in the ultimate outcome. Id. Winner-take-all was the greatest contributor to the 2016 outcome, as Hillary Clinton would have won the electoral vote under a proportional scheme. See Lawrence Lessig, The Equal Protection Argument Against 'Winner-Take-All' in the Electoral College, Medium (Dec. 4, 2016), https://medium.com/equal-citizens/theequal-protection-argument-against-winner-take-all-in-the-electoral-collegeb09e8a49d777 [https://perma.cc/FAM2-84A8]. Likewise, the inefficient distribution of Grover Cleveland's votes in 1888 from a winner-take-all perspective was a significant contributor to his electoral defeat. BEST, supra note 9, at 65. Under fractional proportional allocation, George W. Bush would have won a bare plurality of less than half an electoral vote, although he would not have attained the 270 electoral votes necessary, under current rules, to prevent the election from being decided in the House of Representatives. See KozA ET AL., supra note 3, at 134-35. ("Even though Al Gore led by 537,179 popular votes nationwide, he would have received only 268.766 electoral votes, whereas George W. Bush would have received 269.234 electoral votes.").

23. See KozA ET AL., supra note 3, at 255 (explaining that there have been six such elections in the past 60 years).

24. See infra Part II.A.4.

25. See KozA ET AL., supra note 3, at 434-41.

26. See id. at 43-47 (noting that swing states tend to benefit more from federal funds than other states).

27. See infra notes 202-204 and accompanying text. 
votes, in some cases, 30,000 times more power to determine the ultimate outcome than is true for votes by residents of other states. ${ }^{28}$ Moreover, because of the immense benefits winner-take-all confers on a candidate who ekes out even a tiny plurality, it creates significant incentives to engage in state-level fraud, as has occurred in past elections, ${ }^{29}$ or efforts at voter suppression - a problem both historically and currently.$^{30}$ Notably, winner-take-all's potential to produce harmful results has long been recognized in the context of party primaries; the Democratic Party, in light of these concerns, has prohibited winner-take-all primaries since $1968,{ }^{31}$ and, despite their partial use in the Republican Party, they have been the subject of heated criticism from some Republicans, particularly during the primary election of $2016 .{ }^{32}$

Fourth, the winner-take-all system is notable for its lack of historical or intellectual justification. To be sure, all of the electoral college's features that tend to produce results at odds with the popular vote are controversial. Both the two-vote bonus and population-based allocation, for example, have been associated with efforts to preserve slavery and to justify disenfranchisement of particular groups of voters. ${ }^{33}$ Both likewise have the potential to create an electoral-popular vote split on their own, and the two-vote bonus was in fact a substantial contributor to George W. Bush's 2000 electoral victory. ${ }^{34}$ Yet both these devices - as this Article will go on to discuss - can be defended by arguments that, whether or not one agrees with them, are at least legitimate and reasoned. Further, both mechanisms are the result of national compromises achieved after the consideration of many other options. ${ }^{35}$

28. See infra notes 211-214 and accompanying text.

29. See BEST, supra note 9, at 25 (discussing voter fraud in the 1876 presidential election).

30. See infra Part II.A.2.

31. See infra note 238 and accompanying text.

32. See Terry Connelly, It's the Delegate Count, Stupid! GOP's Tricky Primary Vote Allocation Rules Mean "Get Down to Three or Trump's Home Free", Huffington POst (Feb. 25, 2016), http://www.huffingtonpost.com/terryconnelly/its-the-delegate-count-st_b_9301800.html [https://perma.cc/Z7R D-GCLX] (describing non-proportional delegate allocation rules as a "doomsday machine for GOP leaders who fear a Trump nomination").

33. See, e.g., Mark Joseph Stern, The Electoral College Is an Instrument of White Supremacy and Sexism, Slate, (Nov. 11, 2016), http://www. slate.com/blogs/xx factor/2016/11/11/the electoral college is an instr ument_of_white_supremacy_and_sexism.html [https://perma.cc/7D9CHTXA].

34. See infra note 62 and accompanying text.

35. See infra Parts I.A-B. 
By contrast, states adopted winner-take-all systems with virtually no systematic deliberation at the state or national level about their overall effects on the process and outcome ${ }^{36}$ In most subsequent discussions of electoral college reform, winner-take-all has been subject to blistering criticism, and even those who continue to defend the electoral college often ignore or minimize its effects. ${ }^{37}$ Further, whereas the twovote bonus and total-population allocation deviate from the popular vote by design, winner-take-all crowns popular-vote losers for entirely arbitrary reasons. While the argument, for example, that that small states should have sway over the presidential outcome sufficient to ensure their relevance is no means incontestable, it is at least colorable. By contrast, it is hard to think of a principled justification for permitting an individual New Hampshire resident 30,000 times more influence in a presidential election than that of a resident of Wyoming, as one analysis suggests has been the case in recent elections. ${ }^{38}$

Fifth, from a more pragmatic point of view, a move to change the winner-take-all system at the national level potentially lacks one obstacle that other electoral college reform efforts have encountered: the opposition of states that believe they will lose power if the reforms are a success. The bonuses given to states with a small population or a large percentage of nonvoters generally play a minor role in the operation of the electoral college overall. But they may loom larger in the calculus of an individual state that may be required to give up half or more of its influence if a wholly popular-vote-based system were instituted. In 1969, for example, a constitutional amendment to abolish the electoral college that had passed the House by a wide margin failed in the Senate at least in part because of the opposition of small-state senators, one of whom, Carl T. Curtis of Nebraska, commented, "I'm not authorized to reduce the voting power of my state by 20 percent[.]" ${ }^{39}$

36. See infra note 107 (noting that the states "succumbed" to the pressure of winner-take-all).

37. See infra Part III.A.

38. See infra notes 211-214 and accompanying text.

39. Electoral College Reform Victim of Senate Filibuster, CQ Almanac 1970 (1971), https://library.cqpress.com/cqalmanac/document.php?id=cqal701291702. To be sure, a move away from winner-take-all would also shrink the immediate influence of current battleground states. But because only a handful of states enjoy battleground status to begin with and those states shift somewhat from election to election, it is far less clear that such a change would produce permanent winners and losers. Further, while winner-take-all grants additional influence to battleground states, that influence comes at the expense of accurate representation of its population: Because battleground states are by definition closely divided, awarding all votes to one candidate or another ensures that the wishes of approximately half their voters are entirely ignored in presidential elections. 
This Article argues that, for all these reasons, critiques of the electoral college should focus on winner-take-all as its primary fault. This is not to say that objections to the electoral college's other undemocratic mechanisms are unjustified or that more sweeping reform proposals are not a viable solution. Indeed, it is obvious, for example, that direct election of the president by popular vote would immediately eliminate the problems brought about by winner-take-all. Nonetheless, arguments against the electoral college should focus on winner-take-all because it causes the most harm with the least justification. Further, a national reform effort that narrowly targeted winner-take-all-even while preserving the electoral college's other counter-majoritarian features - would be a vast improvement over the current system, producing less arbitrary outcomes and fewer attendant difficulties..$^{40}$

This Article proceeds in three parts. Part I details the development of the three mechanisms discussed - the two-vote bonus, populationbased electoral vote allocation, and the winner-take-all system - arguing that the third differs sharply from the former two in the degree of deliberation with which it was adopted and the extent to which it represents a reasoned national compromise. Part II details the many ways in which winner-take-all has had deleterious effects on both the presidential election process and the fair representation of all state citizens. Part III discusses past and present efforts at electoral college reform and how these should be evaluated in light of the concerns attending the winner-take-all system. This Article concludes by arguing for a focus on eliminating winner-take-all in efforts to make the U.S. presidential election process fairer and less arbitrary.

\section{The Historical Development of the Electoral College's Counter-majoritarian Features}

Three mechanisms exist through which the electoral college could plausibly yield a result that diverges from the popular vote: the twovote bonus, the allocation of electoral votes based on population, and the award of electoral votes, in 48 states, on a purely winner-take-all basis. These features, while often considered together, have very differ-

40. An example of such a proposal is Senator Howard Cannon's proposed constitutional amendment in 1969 to replace winner-take-all with a system under which each state's electoral votes would be apportioned to three decimal places based on the proportion of the state vote received by each candidate. KOZA ET AL., supra note 3, at 130-32. Such proposals bring their own problems to be resolved, such as the need to splinter electoral votes and the worry that a substantial showing by a third-party candidate could throw many elections into the House of Representatives. As this Article will argue, however, there are acceptable solutions to these issues, some of which have already been pioneered in party primary systems. 
ent histories and justifications, and differ in the overall contribution they have made to electoral results. The following Section traces the development of each of these mechanisms in turn.

\section{A. The "Constant Two" Small-State Bonus}

When electoral college critics enumerate the institution's flaws, they have often focused on the effects of the two-vote bonus given to each state to represent its senators ${ }^{41}$ - a bonus that is provided to all states but that, like the Senate itself, has the effect of giving lowpopulation states disproportionate representation. Legal scholars, for example, have characterized the electoral college as "skew[ing] somewhat away from one-person, one-vote, and in favor of smaller states because of the extra two votes attributable to Senate seats." ${ }^{2}$ This feature, it is argued, "dramatically increases the possibility that the less popular candidate becomes President" because "representation in the Senate is unrelated to population." 43 A frequently cited example of this disparity compares the electoral representation of the most populous state, California, where an electoral vote represents approximately three times more people than it does in the lowest-population state, Wyoming. ${ }^{44}$

In popular and media discussions, commentators often emphasize the effects of the two-vote bonus as well. ${ }^{45}$ Following Al Gore's loss in the electoral college despite a half-million popular vote victory, attention again focused on the small-state bias. For example, in a New York Times opinion piece entitled It Pays to Win the Small States, Alex Keyssar argued that George W. Bush's electoral college victory was

41. See U.S. ConsT., art. II, § 1 (providing that a state's electoral votes should be "equal to the whole Number of Senators and Representatives to which the State may be entitled in the Congress").

42. Paul A. Diller, Reorienting Home Rule: Part 1-The Urban Disadvantage in National and State Lawmaking, 77 LA. L. REv. 287, 334 (2016).

43. Jack M. Beermann, The New Constitution of the United States: Do We Need One and How Would We Get One?, 94 B.U. L. REv. 711, 736 (2014).

44. See, e.g., KozA ET AL., supra note 3, at 56 n.114; see also Katy Collin, The Electoral College Badly Distorts the Vote. And It's Going to Get Worse., WAsh. Post (Nov. 17, 2016), https://www.washingtonpost.com/news/ monkey-cage/wp/2016/11/17/the-electoral-college-badly-distorts-the-voteand-its-going-to-get-worse/?utm_term=.a15687a38c5c [https://perma.cc/JQ 4Z-BU56].

45. See Adam Schleifer, Interstate Agreement for Electoral Reform, 40 AKRoN L. REv. 717, 722 (2007) ("Civics class wisdom has it that the Electoral College system expresses values of federalism by encouraging candidates to vie for small states because those states are disproportionately represented by virtue of the two votes that each state receives under the Senate add-on feature of the Electoral College."). 
attributable to his strong performance in small-population states, concluding that " $[\mathrm{t}]$ hose who tout the virtues of the Electoral College should confront the mathematical reality of the inequities they are defending." ${ }^{46}$ In the wake of another electoral-popular split in 2016, Donald Trump's electoral victory was frequently attributed to the twovote bonus and the resultant small-state advantage. In the Washington Post, Katy Collin argued that small-state overrepresentation "distorts the popular vote in a way that disproportionately rewards those who live in scarcely populated areas," noting that large state and small state disparities in representation have increased since the electoral college first came into being, and are likely to continue to worsen. ${ }^{47}$ Despite reminders that the winner-take-all features of the electoral college tend to overwhelm the effects of the two-vote bonus, ${ }^{48}$ the idea that the main effect of the electoral college is to advantage small states persists.

To some extent, this focus is rooted in history. At the Constitutional Convention of 1787, tensions between large and small states were the "most profound and dangerous of [the] conflicts" 49 that emerged. The Connecticut Plan, or "Great Compromise," settled this issue at least as to representation, ensuring states equal representation in one house of Congress and population-based representation for the other. ${ }^{50}$ Yet the problem resurfaced in the debates about how to choose a president. As delegates settled on the idea of an electoral college, the adoption of the two-vote bonus was driven by the smaller states, who "clearly were concerned that in a straight-out popular election [for president] the larger states would overwhelm them." 51 A particular concern was that voters would tend to throw their support to a candidate from their own state, giving large-state candidates an inherent

46. Alex Keyssar, It Pays to Win the Small States, N.Y. Times (Nov. 20, 2000), http://www.nytimes.com/2000/11/20/opinion/it-pays-to-win-the-smallstates.html?mcubz=0 [https://perma.cc/4S68-PJW8].

47. Collin, supra note 44.

48. See Nate Cohn, Why Trump Had an Edge in the Electoral College, N.Y. Times (Dec. 19, 2016), https://www.nytimes.com/2016/12/19/upshot/whytrump-had-an-edge-in-the-electoral-college.html [https://perma.cc/M8FQ6Z55] (explaining that, while critics of the two-vote bonus "have a point," ultimately "Mr. Trump won for a simple reason: The Electoral College's (largely) winner-take-all design gives a lot of weight to battleground states").

49. See Longley \& Braun, supra note 2, at 23.

50. Id.

51. Shlomo Slonim, The Electoral College at Philadelphia: The Evolution of an Ad Hoc Congress for the Selection of a President, 73 J. Am. Hist. 35, 40 (1986). 
advantage.$^{52}$ While the delegates' concerns about the process of selecting an executive ranged widely, a key factor in winning over small states was the proposal to combine Senate and House representation in determining a state's number of electors - thus ensuring that each state would receive no less than three electoral votes, and the electoral vote disparity between the largest and smallest states would be reduced from about 10:1, as it would be if a purely population-based scheme were used, to about $4: 1 .^{53}$ In reaching this agreement, which has been described as a "jerry-built contraption" designed with the comforting foreknowledge that George Washington would be selected as president in any case ${ }^{54}$ the delegates were guided less by "some grand concept of political theory" ${ }^{15}$ than by more practical considerations, ${ }^{56}$ foremost among them the need to resolve the differences between large and small states. $^{57}$

Although the two-vote bonus was important in fashioning agreement at the Constitutional Convention between large and small states about how the president should be elected, commentators have noted overwhelmingly that the benefit it confers upon small states is modest and generally overwhelmed by the impact of winner-take-all, which magnifies the importance of winning large states. ${ }^{58}$ Candidates can simply garner the required electoral votes to become president more

52. Id. (citing comments of Roger Sherman of Connecticut in The RECORDS OF the Federal Convention of 1787, Vol. 2, 29 (Max Farrand, ed. 1937)).

53. See Slonim, supra note 51, at 51-52 (describing the inclusion of Senate representation in determining electoral votes as "the really critical point" for small states).

54. See AвBott \& Levine, supra note 6, at 11.

55. See Slonim, supra note 51, at 57.

56. See Aввотt \& Levine, supra note 6, at 10 ("It has been argued that the electoral college scheme was less a product of wisdom and philosophy than the result of a practical compromise.").

57. See Slonim, supra note 51, at 57-58.

58. See Michael J. O'Sullivan, Artificial Unit Voting and the Electoral College, 65 S. CAL. L. REv. 2421, 2428-31 (1992) (observing that while the two-vote bonus superficially appears to give more power to the small states, the greater effect of winner-take-all makes the bonus largely irrelevant); Аввотт \& LEVINE, supra note 6, at 78 (explaining that the electoral college's "modest small-state apportionment bias is more than offset by a much larger countervailing bias favoring the largest states, one that results from the winner-take-all feature of the electoral college system and from the patterns of two-party competition in the states") (emphasis omitted). Indeed, the delegates to the Constitutional Convention probably recognized as much. See LONGLEY \& BRAUn, supra note 2, at 28 (noting that "if anything, [the electoral college] was seen as favoring large states - or at least the principle of population"). 
easily if they win states that have more of them. Thus, small states' influence on the outcome tends in most elections to be minimal, although the 2000 election is a partial exception. ${ }^{59}$ Further, small states tend to receive little attention from candidates during presidential campaigns, ${ }^{60}$ particularly because many of the smaller states are dominated by one political party and thus are unlikely to be in play in presidential elections. ${ }^{61}$ Finally, at least from a broad historical perspective, the twovote bonus has not tended to consistently advantage one party over the other. ${ }^{62}$ Yet despite the modest impact the two-vote bonus has generally had, it has tended to dominate popular commentary about the electoral college. Further, although some small states have supported past efforts at electoral college reform, others have worried about the loss of influence that eliminating the bonus would entail. ${ }^{63}$

59. See infra note 62 and accompanying text.

60. See KOZA ET AL., supra note 3, at 450.

61. Almost three decades ago, Abbott and Levine observed that "most of the states with fewer than ten electoral votes are presidentially noncompetitive." See Aввотt \& Levine, supra note 6, at 81. This remained the case in the 2010s. KOZA ET AL., supra note 3, at 444 (noting that "[c]ampaign events were held in only three of the 25 smallest states in 2012 ").

62. Of the last four elections, for example, the bonus has favored Democrats in 2008 and 2012 and Republicans in 2004 and 2016; in none of these elections would eliminating the bonus have altered the electoral result. See generally David Leip, 2016 Presidential General Election Results, AtLAS OF U.S. PResidential Elections, http://uselectionatlas.org/RESULTS/ [https:// perma.cc/Z3MX-P2EG] (last visited Sept. 30, 2017). It should be noted, however, that an exception to the general irrelevance of the two-vote bonus to the result is the 2000 election. Al Gore would have won that election had the two bonus votes been subtracted from every state and would likely not have won had the two-vote bonus been maintained but electoral votes allocated proportionally within states. Even among the four split electoralpopular vote elections, however, the 2000 election is unusual for the exceptional closeness of both the popular vote and the electoral vote. In that election, Gore's winning margin was 0.51 percent of the popular vote, but Bush won 271 to 267 electoral votes - though Gore ultimately received only 266 votes due to a faithless elector. See $i d$. By contrast, in the 2016 election, which again featured split winners but a more lopsided popular and electoral vote, Hillary Clinton would not have won the electoral vote even had the two-vote bonus been eliminated, yet would have won a bare majority of electoral votes had proportional rather than winner-take-all allocation been in effect. See Lessig, supra note 22 (demonstrating that Clinton would have won 270 electoral votes with proportional allocation, regardless of whether or not rounding was used). This analysis assumed a 5 percent popular vote threshold for receiving proportional electoral votes. $I d$.

63. See, e.g., supra note 39 and accompanying text; T.R. Reid, Direct Presidential Election Again Sought by Sen. Bayh, WAsh. Post (Jan. 28, 1977), https://www.washingtonpost.com/archive/politics/1977/01/28/ direct-presidential-election-again-sought-by-sen-bayh/312e9eb5-3418-486f- 


\section{B. Population-Based Representation in the Electoral Vote}

The electoral college's allocation of voting power based on population is only occasionally discussed in modern critiques, but the issue has been an important one historically. At the Constitutional Convention, the Connecticut Compromise - which divided legislative representation between one population-based body and one in which each state would have two votes - had already revealed common ground between the slave and small states. ${ }^{64}$ During the Convention, small states and slave states likewise allied against a system of popular election, albeit for opposite reasons: the small states wanted a system not strictly based on population to protect them from what they saw as a large-state bias, while the slave states wanted to leverage the representational advantage they gained from the disenfranchised slave population, which counted three-fifths of the free population for purposes of both congressional and electoral representation. ${ }^{65}$

Despite initial conflicts between northern states that wanted to exclude slaves from the basis of representation and southern states that wanted them to count equally, the delegates fairly readily agreed on the notorious solution under which the slave population would count three-fifths of the free population. ${ }^{66}$ The three-fifths clause was in keeping with the delegates' still-inchoate ideas about the fundamental nature of democratic representation, in which the concept was linked to property and labor ${ }^{67}$ - the expenses of the earlier Confederation, for example, had been apportioned on the basis of the relative value of real estate in each state. ${ }^{68}$ Yet while the three-fifths formula initially "went over rather smoothly" during the convention and later ratification, it ultimately came to be perceived as "a major victory for the South . . . consistently augment[ing] southern representation in the

8ffacf6e436b62df/?utm_term=.5147e7aa92bb [https://perma.cc/Q6DX8V9B] (noting a Nevada senator's opposition to direct election on the grounds that small states would be ignored).

64. Slonim, supra note 51, at 41.

65. Id.

66. See Don E. Fehrenbacher, The Dred Scott Case: Its Significance in American Law And Politics 20 (1978).

67. See id. at 21-22 (quoting Charles C. Pinckney's statement during the ratification debates as characterizing the three-fifths apportionment mechanism as a method of assessing "productive labor of [our] inhabitants" and providing the south "representation for our property"). Though such statements are sometimes regarded as evidence that delegates viewed slaves as property, Fehrenbacher argues that they were more a product of the delegates' "muddled thinking" about the nature of representation and the "widespread belief in the relative inefficiency of slave labor." Id.

68. Id. at $19-20$. 
House by thirty per cent or more." 69 The super-representation of southern whites in the House obviously enhanced their power in the electoral college as well and allowed them, in the years leading up to the Civil War, to dominate all branches of government through what Don E. Fehrenbacher has described as "a kind of holding-company arrangement, in which the South was the majority section within the Democratic party, and the Democrats were the majority party of the nation." Though northerners chafed at this disproportionate southern influence, they saw little hope of changing the three-fifths clause, built as it was into the structure of the Constitution. ${ }^{71}$

After the Civil War, however, the legislators of the Thirty-Ninth Congress turned with renewed attention to the issue of how representation should be determined. As Congress debated various provisions in what was to become the Fourteenth Amendment, it had to grapple with the same fundamental issue the Constitutional Convention had faced-how to allocate representation in a world where women and freedmen made up a large share of the population but were still generally disenfranchised. ${ }^{72}$ The legislators turned a serious eye to this task, conscious of its momentousness. As one representative put it, "The footprints of this Congress will be upon the rocks of the mountains. . . . [T] here has never been a day . . . when . . . the wisdom of Congress has been so imperatively demanded as now." 73

The Republican-controlled Congress was acutely aware that the three-fifths compromise had allowed slave states to expand their influence in Congress and the electoral college, and was determined that the postwar South must not be permitted to engage in the same maneuver. Legislators feared the scenario in which the ex-Confederate states would be able to expand the power of their white population at the federal level by counting disenfranchised freedman in determining their representation. Various representatives railed at the unfairness of using former slaves to bolster the representation of former slaveholders who refused to allow the freedmen equal civil privileges. ${ }^{74}$

69. Id. at 20 .

70. Id. at 511.

71. Id. at $20-21$.

72. See Ellen Carol DuBois, Woman Suffrage and Women's Rights 9394 (1998).

73. Cong. Globe, 39th Cong., 1st Sess. 1088 (1866) [hereinafter Globe] (comments of Rep. Woodbridge).

74. As Rep. Conkling explained: "The three-fifths rule gave the slaveholding States over and above their just representation ... [ [t] he new situation will enable those States when relationships are resumed, to claim twenty-eight Representatives [representing their black population] beside their just proportion. Twenty-eight votes to be cast here and in the Electoral College 
Exactly how to avoid this scenario, however, was a more difficult question. Legislators were skeptical that a constitutional amendment directly enfranchising blacks could be ratified by the required number of states. ${ }^{75}$ Further, while earlier notions that had linked representation to labor or property no longer found widespread adherence, there was no obvious consensus around an alternative model. A possible solution that emerged was to base congressional - and thus electoral collegerepresentation solely on the voting population, putting ex-Confederate states to a choice between giving freedmen the vote or effectively accepting a reduced representation in Congress and in presidential contests. ${ }^{76}$ As one representative urged, such a plan would reflect "the fundamental idea of all just representation, that every voter should be equal in political power all over the Union." $" 77$

Various legislators, however, raised objections to this plan. Some pointed out, for example, that it would unfairly benefit the western states, which were predominantly male and thus had a higher proportion of voters. ${ }^{78}$ Legislators further argued that adult male voters could take into account the interests of their female or minor family members, who would be excluded from such virtual representation if only voters were considered. ${ }^{79}$ Others contended that states might seek

for those held not fit to sit as jurors, not fit to testify in court, not fit to be plaintiff in a suit, not fit to approach the ballot-box." Id. at 357 (comments of Rep. Conkling).

75. See id. at 879 (comments of Sen. Hendricks) (arguing that Section 2 was a disguised attempt at black enfranchisement from legislators who "dare not go before the [state] [1] egislatures for the ratification of the direct proposition"). See also 2 Bruce Ackerman, We the PeOple: TRANSFORMATIONS 106 (1998) (noting that congressional Republicans were "painfully aware" that only a handful of northern states had granted blacks the vote).

76. See Globe, supra note 73, at 141 (comments of Rep. Blaine) (describing various proposals to "mak[e] suffrage instead of population the basis of apportioning Representatives").

77. See id. at 404 (comments of Rep. Lawrence) (objecting to population-based representation on the grounds that it lacked this feature of just representation).

78. See id. at 141 (comments of Rep. Blaine) (explaining how the plan would benefit California, a state with a high population of vote-eligible men); $i d$. at 357 (comments of Rep. Conkling) (mocking the view that objections to suffrage-based proposals were based on "the fear of taking away power from fanatical New England"); id. at 433 (comments of Rep. Broomall) (suggesting that a voter-based scheme might cause "injustice . . . between the extreme East and the extreme West").

79. Rep. Blaine, for example, argued that "no one will deny that population is the true basis of representation; for women, children, and other non-voting classes may have as vital an interest in the legislation of the country as those who actually deposit the ballot." Id. at 141 (comments of Rep. Blaine). 
to gain an advantage by rushing to grant the vote to women, minors, new residents, or foreigners - a "strife of unbridled suffrage," according to Rep. Roscoe Conkling. ${ }^{80}$ Finally, some suggested that allocating representation on the basis of voters might be considered as tacitly approving continuing disenfranchisement of freedmen. ${ }^{81}$

An alternative possibility, one around which Congress eventually coalesced after long debate, was to continue to calculate House and electoral representation on the basis of population, but to penalize any disenfranchisement of the adult male population. In final form, Section 2 of the Fourteenth Amendment was an effort to accomplish this purpose, continuing the apportionment of representation on the basis of states' "respective numbers," but going on to provide that should the vote be "denied to any of the [adult] male inhabitants of such State, being . . . citizens . . except for participation in rebellion, or other crime, the basis of representation therein shall be reduced in the proportion [to the percentage of the population disenfranchised]." 82 The inclusion of the word "male" ${ }^{83}$ - the first-ever reference to sex in the

Likewise, Rep. Bromwell argued that "[l]adies are a part of the family with most of us," such that their interests could be considered by male voters, while blacks were "not ... of the white family" and required the ability to vote on their own behalf to ensure their perspectives would be represented. See id. at 410 (comments of Rep. Bromwell). See also id. at 411 (comments of Rep. Cook) (arguing that women and children "are represented, in the true sense of that word, by their fathers and brothers"). Conversely, others noted the distortion in the preferences of blacks inherent in including them in the basis of representation but denying them the vote: "[A]n oppressed race should not lend power to their oppressors," argued Rep. Donnelly. Id. at 377 (comments of Rep. Donnelly).

80. See id. at 357 (comments of Rep. Conkling). Rep. Blaine likewise spoke of a possible "unseemly scramble" to extend suffrage to groups such as foreigners. See id. at 141 (comments of Rep. Blaine).

81. See, e.g., id. at 536 (comments of Rep. Stevens) (addressing arguments that representation-reducing mechanisms gave an "implied permission" to states to regulate the franchise more restrictively); $i d$. at 673 (comments of Sen. Charles Sumner) (objecting to the proposal as a "delusion and a snare" that would constitute tacit acquiescence in disenfranchisement by race).

82. U.S. Const. amend. XIV, § 2.

83. Initial versions of the amendment were phrased differently; an earlier draft provided that "whenever the elective franchise shall be denied or abridged in any State on account of race or color, all persons of such race or color shall be excluded from the basis of representation." GLOBE, supra note 73, at 351 (comments of Rep. Stevens). Some representatives objected to this language on grounds that it would make it too difficult to impose qualifications, such as literacy, on the franchise. See, e.g., id. at 355 (comments of Rep. Rogers) (arguing that a literacy requirement that barred one black man from voting would trigger this provision and prevent all black men in the state at issue from counting towards that state's population). Others wondered about effects on exclusion of other minority groups, such 
U.S. Constitution ${ }^{84}$ - was controversial ${ }^{85}$ and opposed by woman suffrage advocates ${ }^{86}$ but it solved a difficult problem-how to disadvantage states that disenfranchised on the basis of race in a country not yet ready to exact a similar penalty for failing to extend the franchise to women. ${ }^{87}$ Senator Charles Sumner is reported to have said that he "wrote over nineteen pages of foolscap [in an effort] to get rid of the word 'male' and yet keep 'negro suffrage' as a party measure intact; but it could not be done." 88

Although the subsequent passage of the Fifteenth and Nineteenth amendments has mooted some of the arguments separating proponents of voter-based and population-based schemes, the dispute remains relevant in many respects. ${ }^{89}$ States still differ markedly in their non-voting population percentages, in some cases because of voter turnout differences, in others because of relatively larger populations of children, non-citizens, or felons. ${ }^{90}$ Further, perspectives on the fairness of this

as Chinese immigrants, see e.g., id. at 376 (comments of Rep. Brooks); suggested that the categories of race and color might be underinclusive, see e.g., id. at 409 (comments of Rep. Bromwell) (discussing other possible requirements states could enact resulting in disenfranchisement on other grounds); or worried about practical problems of administration, see e.g., id. at 535 (comments of Sen. Benjamin) (referencing Missouri's requirement that, in order to vote, men had to take an oath that they did not aid or give comfort to the enemy during "the rebellion").

84. See DuBois, supra note 72 , at 93 ("The amendment included the first reference in the Constitution to the distinction of sex.").

85. Rep. Thaddeus Stevens, for example, objected to an initial proposal to use the word "male," stating, "[w]hy has [Rep. Schenck, the author] used that word 'male'? It was never in the Constitution of the United States before. Why make a crusade against women in the Constitution of the nation?" GLOBE, supra note 73, at 536 (comments of Rep. Stevens).

86. See DuBois, supra note 72, at 93-94.

87. See 2 Elizabeth Cady Stanton et al., History of Woman Suffrage 91 (1881) (noting that legislators reportedly remarked that "[s]uffrage for black men will be all the strain the Republican party can stand").

88. Id.

89. For more contemporary takes on the issue of population-based apportionment and virtual representation, see Joseph Fishkin, Weightless Votes, 121 YALE L.J. 1888 (2012) (discussing the tension between representation based on the voting population and the total population of a jurisdiction, and how the current system protects certain numerical groups), and Robert W. Bennett, Should Parents Be Given Extra Votes on Account of Their Children?: Toward A Conversational Understanding of American Democracy, 94 Nw. U. L. REv. 503 (2000) (applying the concept of "one person, one vote" to parents with minor children).

90. See Gaffney v. Cummings, 412 U.S. 735, 746-47 (1973) ("The proportion of the census population too young to vote or disqualified by alienage or 
situation continue to differ. Some have argued in particular against what has been called the practice of "prison gerrymandering" - counting disenfranchised prison populations as part of their place of incarceration rather than as part of their home communities ${ }^{91}$ —or objected more generally that any alignment of interests between ineligible adults and the voting population is, at best, "highly uncertain." ${ }^{92}$ In contrast, other commentators have spoken in favor of population-based representation, noting, for example, that it enables a "fairly simple assessment of the balance of political power by counting population" 93 and cautioning that "[t]here is value in having a government that represents all of the people living in its jurisdiction and subject to its laws, a value we ought not to trade away lightly." ${ }^{4}$ Many of these arguments echo those made at the Constitutional Convention and, especially, at the 39th Congress: Is it wrong to include nonvoters in a state's power base when their political preferences may be quite different from those of the voting population? Or, conversely, should populations, such as young children, that cannot vote for some good reason nonetheless be entitled to be included in determining a state's political clout? ${ }^{95}$ Historically, these issues have proved difficult to resolve, and they have the potential to continue to cause controversy today.

\section{The Evolution of Winner-Take-All}

In contrast to the two-vote bonus and population-based apportionment, the use of winner-take-all electoral vote allocation, also called the "unit rule," ${ }^{96}$ was not adopted at a national level. Although the Constitution provided for the appointment of electors "in such Manner as the

nonresidence varies substantially among the States and among localities within the States.").

91. See Michael Skocpol, Note, The Emerging Constitutional Law of Prison Gerrymandering, 69 STAN. L. REV. 1473, 1476 (2017) (summarizing arguments that "counting inmates at their prison 'residences' deprives their home communities - disproportionately minority, urban, and poor - of political clout they might otherwise enjoy if prisoners were counted at their preincarceration addresses").

92. Bennett, supra note 89, at 533. Bennett does note nonetheless that, however imperfect, "there may . . . be no practical alternative" to a scheme of virtual representation for nonvoting populations. Id. at 535.

93. Derek T. Muller, Invisible Federalism and the Electoral College, 44 ARIZ. ST. L.J. 1237, 1249 (2012).

94. Fishkin, supra note 89, at 1910.

95. See supra notes 73-81 and accompanying text.

96. See Aввот \& Levine, supra note 6, at 15 (discussing the adoption of the unit rule by state governments, "one state follow[ing] another in switching to a winter-take-all system"). 
[state] Legislature[s] . . may direct,"97 the winner-take-all system was, to begin with, not a part of the delegates' original vision for the electoral college; there was no discussion of the idea in either the Constitutional Convention or the Federalist Papers..$^{98}$ Indeed, a practice like winnertake-all was inherently inconsistent with the original premise of the electoral college, under which independent electors would exercise reasoned deliberation in choosing among candidates. ${ }^{99}$

This original vision of the electors, however, soon proved incomepatible with a system dominated by political parties, and by 1796 it had become apparent that "the processes of selection of the electors in the states would be dominated by partisan, not personal, considerations." 100 Even as the electoral college's nature and function became blurred, however, winner-take-all mechanisms scarcely came into play; while three states established winner-take-all voting in the first election of 1789 , all had repealed it by $1800 .{ }^{101}$ Meanwhile, problems had begun to arise with the workings of the electoral college, under which each elector cast two votes and the runner-up became vice president. ${ }^{102}$ In 1796, this resulted in a president and vice president from different parties, while in 1800, Jefferson became locked in a tie with his running mate Aaron Burr in an election ultimately resolved in the House after lengthy and tumultuous proceedings. ${ }^{103}$ As a result of these clear breakdowns of the electoral college process, momentum quickly built for reform, and by September 1804, in time for that November's election, the

97. U.S. Const., art. II $§ 1$.

98. See KOZA ET AL., supra note 3 , at 366.

99. See $i d$. ("[T]he Founding Fathers envisioned an electoral college of 'wise men' who would . . . exercise independent and detached judgment as to the best person to serve as President."); FEDERALIST No. 64 (John Jay) (expressing belief that "select bodies of electors" will have an advantage over popular elections tainted by "the supineness, the ignorance, and the hopes and fears of the unwary and uninterested"); FEDERALIST No. 68 (Alexander Hamilton) (arguing that the choice of an executive should be made by "men most capable of analyzing the qualities adapted to the station, and acting under circumstances favorable to deliberation and to a judicious combination of all the reasons and inducements that were proper to govern their choice"). See also Ross, supra note 21, at 157 (noting that Madison came to believe that winner-take-all was inconsistent with the Framers' original intent).

100. Аввотt \& Levine, supra note 6 , at 12.

101. KOZA ET AL., supra note 3, at 366 .

102. See Aвbott \& Levine, supra note 6, at 13 (discussing how Federalist John Adams received the most votes and became president, while DemocraticRepublican Thomas Jefferson was elected vice president).

103. See id. at $13-14$. 
Twelfth Amendment, providing that electoral votes were to be cast separately for president and vice president, had been ratified. ${ }^{104}$

The Twelfth Amendment, however, did not change state legislatures' right to choose the manner in which electors are selected, and throughout the early 1800s, many legislatures appointed electors on their own without popular input. ${ }^{105}$ Eventually, however, pressures for a more democratic process prompted all states to allow direct voting for electors, and all but South Carolina had incorporated a democratic element by $1832 .{ }^{106}$ While some states initially provided for voting by district, eventually almost all states succumbed to the "competitive pressure" provided by winner-take-all, or "general ticket" systems, as they were then called. ${ }^{107}$ Winner-take-all-enabled states could "deliver a solid bloc of electors to their party's national ticket, thereby buttressing its claims for patronage and other rewards from the new administration." 108 By 1868, all states had adopted a popular-election, winner-take-all system, which they have maintained ever since with only three exceptions, ${ }^{109}$ of which just two-district-based voting in Maine and Nebraska- persist today. ${ }^{110}$

Even as the winner-take-all system was tacitly becoming the norm, some criticized it as unfair. In 1824, Missouri Senator Thomas Hart Benton observed that while "los[ing] their votes is the fate of all minorities," the operation of the unit rule was "not a case of votes lost, but of votes taken away, added to those of the majority, and given to a

104. See id. at 14; U.S. Const. amend. XII.

105. See Aввотt \& Levine, supra note 6, at 15.

106. Id.

107. $I d$.

108. Id.; see also LONGLey \& PeIRCE, supra note 11, at 25 ("Generally, division of a state's electoral votes was supported by whatever party was momentarily in eclipse in a state, while the dominant party supported a winner-take-all arrangement. Not very surprisingly, the latter's view usually prevailed.").

109. In addition to the two states-Maine and Nebraska - that currently allocate electoral votes by district, Michigan briefly used a district system for the election of 1892. ABBotT \& LeVINE, supra note 6, at 16; LONGLEY \& PEIRCE, supra note 11, at 99. Note, however, that the winner-take-all system in its exact current form has been in existence only since the early twentieth century, since prior to that time ballots listed electors rather than the names of the presidential and vice-presidential candidates. See Norman R. Williams, Reforming the Electoral College: Federalism, Majoritarianism, and the Perils of Subconstitutional Change, 100 GEO. L.J. 173, 181 (2011).

110. See supra note 18 and accompanying text (describing Maine and Nebraska's modified winner-take-all models). 
person to whom the minority is opposed." 111 Jefferson and Madison opposed the winner-take-all general ticket system on similar grounds, arguing that, by ignoring the preferences of the minority, it failed to accurately mirror public sentiment. ${ }^{112}$ Madison also argued that a more fine-grained system was more consistent with the electoral college's original intent. ${ }^{113}$

The election of 1824 - in which Andrew Jackson received the most votes among the states that did not appoint their electors, rather than the prevailing candidate, John Quincy Adams - sparked new concerns about the electoral college's democratic legitimacy, including the wisdom of the winner-take-all system. ${ }^{114}$ In 1826, the House of Representatives considered a constitutional amendment that would have required states to select electors by districts and eliminated the House's role in resolving elections in which no candidate attained an electoralvote majority. ${ }^{115}$ Proponents of the amendment argued that the winnertake-all general ticket artificially magnified popular support and might mislead the president into misreading the public will. ${ }^{116}$ Opponents believed that the power to choose the manner of appointing electors should remain with the states. ${ }^{117}$ Interestingly, they also argued that a district system could create miniature electoral-popular splits on the state level; if a candidate won some districts narrowly, he could win the majority of a state's electoral votes even while failing to win that state's popular vote. ${ }^{118}$ Concerns that issues of this sort would result in an overall loss of state influence contributed to the plan's defeat by a 90 102 vote. ${ }^{119}$

111. See Longley \& Braun, supra note 2, at 19.

112. See Ross, supra note 21 , at 155-57. Interestingly, however, while preferring the district system on principle, Jefferson recognized that a general-ticket system might serve a "pragmatic need to unify a state's electoral vote, especially in the states with a Republican majority" in order to avoid electoral defeat. Id. at 155. Hamilton similarly supported a general ticket system when his party was in power, but as his "party began to dwindle, so did his preference for the general ticket system." Id.

113. See id. at 157 (explaining Madison's proposition to "establish[] elector selection by districts").

114. The election of 1824 is hard to compare to the results of today's electoral vote because many states continued to use legislative selection, rather than the popular vote, to appoint electors. See BEST, supra note 9, at 25; Ross, supra note 21 , at $159-60$.

115. Ross, supra note 21 , at 160.

116. Id. at 161 .

117. Id. at 162 .

118. See $i d$.

119. Id. at 163 . 
Because the only issue in question was whether the state or the district was the more appropriate unit to use when awarding electoral votes, this debate did not go to the heart of the winner-take-all question. No option under consideration would have allowed for electors to be awarded on a purely proportional basis - and, indeed, as legislators recognized, the district system would simply replicate on a smaller scale many of the problems of winner-take-all at the state level. ${ }^{120}$ Yet some of the arguments raised by opponents of the general ticket scheme remain relevant today. In particular, their concern that winnertake-all not only distorts but ignores the minority's wishes continues to raise troublesome issues, particularly when a candidate wins by an extremely narrow margin a state that is effectively split 50-50. This phenomenon has occurred frequently in U.S. history. In 1876, for example, Rutherford Hayes won several states by approximately 1,000vote margins, ${ }^{121}$ and other elections from the same era featured similarly close races, such as Grover Cleveland's win in New York by a 1,149 margin in 1884 and California by 147 in $1892 .{ }^{122}$ Some recent close elections have featured equally narrow wins: John F. Kennedy won Hawaii by 115 votes in 1960, for example, and in 2000 all 25 of Florida's electoral votes were awarded to George W. Bush despite his razor-thin and disputed plurality of 537 votes. ${ }^{123}$

Such results have historically proved troubling not only, as Senator Benton suggested, for their symbolic slighting of half a state's electorate, ${ }^{124}$ but also for the practical mischief they may cause. The winnertake-all system played a significant role in all four popular-electoral vote split elections in which the system has been fully entrenched-that

120. See $i d$. at 162 .

121. See KozA ET AL., supra note 3, at 607-08 (noting that Hayes won South Carolina by 889 votes, Florida by 922 votes, Oregon by 1,050 votes, and Nevada by 1,075 votes).

122. See Leip, supra note 62 .

123. See id.

124. See supra note 111 and accompanying text. 
is, the elections of $1876,1888,{ }^{125} 2000$, and $2016 .{ }^{126}$ This excludes the election of 1824, when-under somewhat different rules-John Quincy Adams prevailed in the electoral college over Andrew Jackson, who won a plurality of the popular votes. ${ }^{127}$

In 1876 - the first election resulting in a popular-electoral split in which the winner-take-all system was securely in place - winner-takeall played a central role in the chaotic result. Although Samuel Tilden prevailed over Rutherford Hayes in the popular vote by 3 percent-a healthy margin, though one likely achieved in part by voter intimidation ${ }^{128}$ - the electoral college result hinged on the outcome of close, disputed results in South Carolina, Florida, and Louisiana, which together accounted for 20 electoral votes. ${ }^{129}$ Widespread allegations of fraud on both sides made it nearly impossible to discern the true winner. ${ }^{130}$ Nonetheless, a Republican-controlled commission awarded the disputed votes to Hayes, permitting him to claim victory by a single

125. Judith Best argues that because of both parties' "widespread fraud in casting and counting the votes," it is "difficult to assert with any confidence" which candidate won the popular vote in 1876 as well. BEST, supra note 9, at 25. It is notable that, if one accepts Best's analysis, the past two decades have produced two of the three clear instances - in 2000 and 2016 - in U.S. history in which the popular vote winner has clearly failed to attain the presidency. But see Twentieth Century Fund Task Force, Winner Take All: Report of the Twentieth Century Fund Task Force on Reform of the Presidential Election Process 39 (1978) (William R. Keech, ed.) (noting that the same corruption and voter intimidation that occurred in 1876 also took place in subsequent elections, and that if a uniform standard were applied, "the victories of Presidents Cleveland and Wilson would be suspect").

126. See Leip, supra note 62 (illustrating the popular-electoral vote split in the 2000 and 2016 elections).

127. There are many reasons to exclude 1824 from discussions of popular electoral splits. As Judith Best points out, six states' electoral votes in that election27 percent of the total electoral votes-were determined by legislative appointment, so it is impossible to undertake a complete tally of the popular vote. See BEST, supra note 9, at 25. Further, several states employed a district-based system rather than winner-take-all. See TwENTIETH CENTURY Fund TASK FORCE, supra note 125, at 37 ("The election of 1824 is not very relevant to current issues because only three-quarters of the states actually held popular elections.").

128. See Longley \& Braun, supra note 2, at 33. Because of the rampant fraud in the election, however, the true margin between the candidates is essentially impossible to reconstruct. BEST, supra note 9, at 25.

129. Longley \& Braun, supra note 2 , at 34 .

130. See id. 
electoral vote, while Democratic opposition was bought off with a "sordid" deal to end Reconstruction. ${ }^{131}$

If the fraud and violence that plagued the election of 1876 illustrated some of the perils of disproportionately rewarding narrow victories in close states, the next popular-electoral split resulted from a more organic feature of the system: the problem that a candidate's support might not be evenly spread across states. In 1888, popular vote winner Grover Cleveland suffered by virtue of his "inefficient" wins by large margins in the south, while electoral vote winner Benjamin Harrison accumulated most of his state wins narrowly. ${ }^{132}$ Cleveland's average vote percentage in the states he won was 5.5 points higher than Harrison's; Harrison won thirteen of his twenty states by margins of 4 points or less. ${ }^{133}$ Although the 1888 election is sometimes cited in support of the proposition that the winner-take-all mechanism favors candidates with national rather than regional appeal, ${ }^{134}$ one commentator has argued compellingly that both Cleveland and Harrison had a regionally concentrated base of support and that the 1888 regional distribution of votes substantially mirrored that of 1880 , in which there was not a popular-electoral split. ${ }^{135}$

More recently, Gore's electoral loss in 2000 was somewhat anomalous in that the popular-electoral split was due as much to the twovote bonus as to winner-take-all: Gore would have won had states been stripped of their "constant two," 136 while under a proportional split of electoral votes he would have come in second by a minuscule margin of about one-half an electoral vote in a result that would have been

131. See id. at 34-35 (explaining that Democrats forewent challenging the commission's decision in exchange for the promised withdrawal of the remaining federal troops in the South).

132. Аввотт \& Levine, supra note 6 , at 25.

133. See id.

134. See BEST, supra note 9, at 65 (discussing 1888 as an example of a "sectionally imbalanced candidacy").

135. See KozA ET AL., supra note 3, at 501-02 (observing that "[i]ndeed most of the post-Civil War elections evidenced a regional pattern" similar to that of 1880 and 1888). See also Vikram David Amar, Response: The Case for Reforming Presidential Elections by Subconstitutional Means: The Electoral College, the National Popular Vote Compact, and Congressional Power, 100 GEO. L.J. 237, 242-44 (2011) (noting that in general, elections since the Civil War have not "been characterized by hodgepodge, noncontiguous patchworks of states supporting the winning candidate" but have instead involved regionally concentrated support).

136. Gore won 19 states and the District of Columbia, while Bush won 31 states. See Leip, supra note 62 (noting that Bush received 22 more electoral votes than Gore from the "constant two," greater than his four-electoral-vote margin of victory). 
essentially a tie, ${ }^{137}$ with neither candidate gaining the "majority of the whole number of Electors" that the Twelfth Amendment currently requires to become president without the involvement of the House of Representatives. ${ }^{138}$ Given the potential resolution of the election by the House and the closeness of the vote overall, it is difficult to say with any confidence what would have occurred in 2000 had winner-take-all not been in place. ${ }^{139}$ In contrast, the disputed outcome of the election and the prolonged legal battle that ensued can be blamed entirely on winner-take-all, which magnified the significance of a handful of Florida votes..$^{140}$

Finally, the 2016 general election was affected by winner-take-all in numerous ways. To begin with, Donald Trump owed his electoral win not to the two-vote bonus but to winning more electoral vote-rich states

137. See KozA ET AL., supra note 3, at 134-35 (showing that, under a proportional approach awarding votes only to candidates surpassing a cutoff point, Gore would have received 268.766 electoral votes, while Bush would have amassed 269.234 electoral votes).

138. U.S. Const., amend. XII. Bush, that is, would have received only a fractional amount more than 269 votes, meaning that neither candidate would have met the required 270 cut-off.

139. See infra notes 140 and 180. Given the closeness of the popular vote, it is quite plausible that the popular vote margin might also have been differentwhether a larger margin for Gore or a winning margin for Bush - had winnertake-all not been in place and the candidates been free to pursue a strategy not focused on swing states.

140. As with the 1876 result, it is nearly impossible to determine who Florida's "true" winner would have been in the absence of Supreme Court intervention; an exhaustive media study of Florida ballots found that, although Bush would have prevailed had the recount gone forward under the methodology that likely would have been used, a full state recount would have awarded the state to Gore. See Ford Fessenden \& John M. Broder, Examining the Vote: The Overview; Study of Disputed Florida Ballots Finds Justices Did Not Cast the Deciding Vote, N.Y. Times (Nov. 12, 2001), http://www.nytimes.com/2001/11/12/us/examining-vote-overview-studydisputed-florida-ballots-finds-justices-did-not.html. [https://perma.cc/3AR $\mathrm{W}-\mathrm{XZ9F}]$. As the reporters noted, "[t]he race was so close that it is possible to get different results simply by applying different hypothetical votecounting methods to the thousands of uncounted ballots. And in every case, the ballot review produced a result that was even closer than the official count - a margin of perhaps four or five thousandths of one percent out of about six million ballots cast for president." In addition, the study found "statistical support" for the idea that faulty ballot design had cost Gore enough votes to sway the election. Id. See also Dennis Cauchon \& Jim Drinkard, Florida Voter Errors Cost Gore the Election, USA TODAY (May 11, 2001), https://usatoday30.usatoday.com/news/politics/2001-05-10-reco untmain.htm [https://perma.cc/4QH4-HWHT] (discussing evidence that voter mistake cost Gore 15,000 to 25,000 votes). 
by narrow margins. ${ }^{141}$ More broadly, Trump's final campaign strategy, which relied in large part on sending negative messages to narrowly targeted groups of Democratic-leaning voters in key states, was shaped by the demands of winner-take-all. ${ }^{142}$

As many have observed, numerous other contests only narrowly avoided an electoral-popular split. ${ }^{143}$ Such a division is a significant threat whenever the country is closely divided; ${ }^{144}$ for this reason, as Abbott and Levine note, the possibility "hung like a dark cloud over every election from 1876 to 1896." 145 The opportunities for a split receded somewhat throughout most of the twentieth century, when both popular and electoral vote landslides became more common. ${ }^{146}$ Yet in the close elections that did occur, a small shift of votes would have produced a difference in the electoral and popular winners. ${ }^{147}$ Further, even some elections featuring a decisive popular margin have come reasonably close to electing the popular vote loser. ${ }^{148}$ With the close partisan divide that has characterized recent elections and the increased focus on battleground states, there is reason to think that the possibility of a popular-electoral split, which has occurred in two out of the five past elections, has increased. ${ }^{149}$

141. See Cohn, supra note 48; Lessig, supra note 22.

142. See infra notes 186-188 and accompanying text.

143. Longley and Braun argue, for example, that, had Alabama's votes been counted a different way - a "perfectly reasonable and possibly even preferable method"-Nixon would have won an electoral college plurality in 1960. LONGLEY \& BRAun, supra note 2 , at 35.

144. See id. at 3 (discussing analysis by Charles Bischoff suggesting that close popular vote margins result in as much as a 50-50 chance of a popularelectoral split). See also KozA ET AL., supra note 3, at 49 (noting that, as of 2012 , one in seven non-landslide elections have resulted in a popularelectoral split).

145. Аввотт \& Levine, supra note 6, at 26 (emphasis omitted).

146. Id. at 28 .

147. See $i d$. (indicating the 1948, 1960, 1968, and 1976 elections as close enough to have produced a "wrong-winner").

148. Abbott and Levine, for example, were initially motivated to write a book on the subject of "wrong winners" after noting that small shifts in state voting totals could have thrown the electoral college to Michael Dukakis in 1988 despite George H.W. Bush's healthy 8-point popular margin. Id. at xii. Indeed, Dukakis's campaign staff began to pursue such a strategy in the campaign's final days. See id. at 32-33 ("Dukakis strategists believed that they had a chance of eking out narrow victories . . . and, perhaps, pulling off an electoral college upset.").

149. See infra note 199 (noting the growth in importance of battleground states); see also KOZA ET AL., supra note 3, at 129 ("Potential problems with the 


\section{The Distinctive Ill Effects of Winner-Take-All}

As the preceding Part argued, winner-take-all-alone among electoral college features that run counter to direct democracy-was never adopted with deliberation or with any idea that it represented a solution or a compromise; ${ }^{150}$ further, it has produced widespread problems throughout U.S history. ${ }^{151}$ This Part argues that, just as it lacks historical legitimacy, the winner-take-all system also lacks contemporary justification. While the electoral college can be reasonably criticized on many grounds, the winner-take-all system stands out for the multiplicity of serious problems it has tended to cause, as well as the lack of offsetting benefits. The following Part explores these issues, first looking at the various difficulties winner-take-all has caused in the presidential election process, then considering the similar issues that a partial winner-take-all system has posed in Republican nomination contests.

\section{A. Winner-Take-All's Negative Effects on the Election Process}

All election systems, of course, have costs, benefits, and tradeoffs. That no perfect process exists has been apparent in the debates over various electoral college reform proposals, from proportional allocation of electoral votes to direct election. Nonetheless, the winner-take-all rule stands out for the degree to which it produces anomalous results, arbitrarily advantages or disadvantages groups of voters, and contributes to various types of political mischief.

\section{Contributing to Arbitrary Electoral-Popular Splits}

The degree to which the winner-take-all system heightens the risk of a popular-electoral split is a significant problem - one that occasioned bipartisan concern in the years before the 2000 election. In a prescient 1991 book, ${ }^{152}$ David W. Abbott and James P. Levine made what they

current statewide winner-take-all system appear to be becoming increasingly common.").

150. See supra notes $96-110$ and accompanying text.

151. See supra notes 121-142 and accompanying text.

152. See Abвott \& Levine, supra note 6. Although the authors were correct about the imminent threat of such a split and many of its particulars - they suggested that it might happen as early as 1996, that one of the affected candidates might be $\mathrm{Al}$ Gore, and that a third-party spoiler candidate might play a role - their prediction was imperfect. Id. at 5-6. They argued that, because of a perceived Republican electoral college disadvantage, a Democrat would be the beneficiary of the split. Id. at 5. Abbott and Levine also failed to foresee the widespread acquiescence in the idea of electing a popular vote loser in 2000 and 2016; they argued that a president who did not win the popular vote would be "politically crippled" and that, following the election 
called the "ominous prediction" that the popular and electoral vote winners would soon diverge, precipitating a "full-fledged constitutional crisis." 153 At the time, even many defenders of the electoral college did not deny that a popular-electoral split was undesirable; rather, they argued that the risk was small and outweighed by positive aspects of the current system. For example, Judith Best, writing a defense of the electoral college in 1975, conceded that an electoral-popular split would be a "misfire" 154 in which the "wrong man" would be elected. ${ }^{155}$ She nonetheless argued that this had happened in only a single election in U.S. history in 1888, maintaining that given allegations of fraud, the true popular-vote winner in the 1876 election was impossible to determine. ${ }^{156}$ She further contended that an 1888-like split was "atypical" and "unlikely to recur frequently" because it occurs "only when a close election coincides with a sectionally imbalanced candidacy or campaign." 157 Alexander Bickel, writing in 1971, likewise believed a popular-electoral split not to be worth worrying about largely because it was "extremely unlikely" 158 and maintained that, due to the irregularities of the 1876 election, 1888 was the sole example in which such a split had occurred. ${ }^{159}$

In the wake of the 2000 election of George W. Bush, despite Al Gore's slim popular vote victory, there was less immediate concern about the possibility of popular-electoral splits, perhaps because of the closeness of that election made the selection of a winner seem a tossup

of such an executive, "[o]ne of the first orders of business of the new Congress . . . would be to begin hearings on proposals for a constitutional amendment to abolish the electoral college." Id. at 46. In terms of prescience, Lawrence D. Longley and Neal R. Peirce also deserve credit for their foresight in imagining - in their 1996 book - disputed outcomes in future elections that would drag on for weeks. See LONGLEy \& PEIRCE, supra note 108, at 15456.

153. Аввотt \& Levine, supra note 6 , at xi.

154. BEST, supra note 9 , at 65.

155. Id. at 71 .

156. See id. at 25 .

157. Id. at $65-66$.

158. Alexander M. Bickel, Reform and Continuity: The Electoral College, the Convention, and the Party System 5 (1971). See also Twentieth Century Fund TAsk Force, supra note 125, at 38 ("Defenders of the Electoral College acknowledge the 1888 deviation but emphasize its remoteness ... [I]t does seem hard to become wrought up over the election of Benjamin Harrison, . . . or the denial of Grover Cleveland, who after all was elected again in 1892 and got to be president as long as anyone except Franklin Roosevelt.").

159. See BICKEL, supra note 158 , at 31. 
to begin with or because attention was focused on the Supreme Court battle over Florida's recount. Following the 2000 election, Ann Althouse, for example, argued that electoral-popular splits were less concerning than many earlier commentators had thought: They were, she argued, likely to occur only in 2000-like circumstances, "a very close race [where] one reasonably strong competitor rather than another wins." 160 She argued further that as between two candidates with roughly equal proportions of the vote, it is hard to argue that awarding victory to either is particularly unfair, contending that in such close races "all one really needs is a device to determine an outcome." 161

Regardless of what one thinks of such efforts to rationalize the 2000 result, the 2016 election should prompt new reflection about both the likely frequency and the legitimacy of popular-electoral splits. It was, to begin with, a significantly more exaggerated example of the phenomenon. In 2000, Al Gore won a bare half-percent popular victory, and George W. Bush eked out a four-vote electoral win. ${ }^{162}$ By contrast, Hillary Clinton won the popular vote by a far more significant 2.1 percent, while Donald Trump's electoral win was also considerably more decisive. ${ }^{163}$ The split was also notable because of its momentous consequences - in contrast to, say, 1888's victor Harrison, whose "impact on the nation was not great," 164 it is possible that Trump's presidency will profoundly alter the course of U.S. history. Nor can the election results - in contrast to what some have argued about 1888 and even $2000^{165}$ _ be attributed to one candidate's narrow regional appeal. While Clinton won fewer states than Trump, she won by wide margins in states as regionally and culturally diverse as California, New Mexico, and Maryland, to name just a few; further, she won several states

160. Althouse, supra note 7 , at 1013.

161. Id. See also Twentieth Century Fund Task Force, supra note 125, at 57 (arguing that in close races, the Electoral College can be seen as a "dignified, authoritative coin flip").

162. Leip, supra note 62 . This figure is based on the results originally certified by the states. Because of one faithless Gore elector, the margin in the final electoral college vote was 271 to 266. Id.; KOZA ET AL., supra note 3, at 115.

163. See Leip, supra note 62 (showing that Clinton won the popular vote by 2.1 percent, while Trump won the final electoral vote by a more than 14 percent margin). The final tally differs slightly from the expected electoral vote because of the seven total defections in the electoral college. See Kyle Cheney, Electoral College Sees Record-Breaking Defections, Politico (Dec. 19, 2016), http://www.politico.com/story/2016/12/electoral-college-electors232836 [https://perma.cc/D2M7-LWQC].

164. Twentieth Century Fund Task Force, supra note 125, at 38.

165. Althouse argues, for example, that in 2000 "[b]oth parties . . risked losing by appealing too much to limited geographical areas." Althouse, supra note 7 , at 1013. 
located within generally Trump-friendly regions, such as Minnesota in the upper Midwest and Colorado among the mountain states. ${ }^{166}$ Finally, 2016 's results can be fairly clearly attributed to the effects of winnertake-all alone, since under the most commonly proposed system of proportional vote allocation, Clinton would have prevailed. ${ }^{167}$

Even apart from whatever one thinks of the specific qualities of candidates Trump and Clinton, it is difficult to come up with a principled reason why our electoral system should favor 2016-like results as opposed to the more straightforward situation in which the popular vote winner is elected president. Trump, that is, did not win the electoral college because the popular vote was decided by a razorthin margin, nor because Clinton appealed only to one or two regions, nor because the small states disproportionately favored him. Rather, he won because of the happenstance that his voters happened to be slightly more efficiently distributed.

Of course, some might not see this outcome as happenstance at all, arguing instead that Trump's electoral win was attributable to superior campaign strategy. Electoral college defenders have frequently suggested that candidates and parties can mitigate the risk of an electoralpopular split by wise campaigning, ${ }^{168}$ and Hillary Clinton's campaign was heavily criticized for devoting insufficient resources to the upper Midwest states she lost narrowly. ${ }^{169}$ Yet some academic research

166. See Leip, supra note 62 .

167. See Lessig, supra note 22 (ruling out the two-vote bonus as the cause of Trump's victory). By contrast, even if all electors had voted for their expected candidates and the two-vote bonus had been excluded, Clinton would not have won a majority of the remaining electoral votes. Clinton won twenty states, plus the District of Columbia, while Trump won thirty, leading to the initial electoral tally, disregarding faithless electors, of 306 to 232. Leip, supra note 62 . Excluding bonus votes, Trump would thus have won 246 electoral votes, while Clinton would have won 190.

168. See BEST, supra note 9, at 66 (suggesting that the "wit and ingenuity of the political parties" will prevent a popular-electoral split); Althouse, supra note 7, at 1012 (arguing that "the decision to campaign efficiently under the requirements of the electoral college plan" can prevent an electoral-popular split).

169. See, e.g., Edward-Isaac Dovere, How Clinton Lost Michigan-And Blew the Election, PoLITico (Dec. 14, 2016), http://www.politico.com/story/ 2016/12/michigan-hillary-clinton-trump-232547 [https://perma.cc/3EYLZP8V] (indicating "state battleground operatives worry that [the] lesson being missed is ... [g] et the basics of campaigning right"). However, this criticism has been disputed by others. See Ronald Brownstein, How the Rustbelt Paved Trump's Road to Victory, AtLANTiC (Nov. 10, 2016), https://www. theatlantic.com/politics/archive/2016/11/trumps-road-to-victory/507203/ [https://perma.cc/RW7K-4RQK] (noting that Clinton suffered a narrow loss in Pennsylvania despite devoting "enormous resources" to the state, suggesting 
suggests that campaign tactics matter less to presidential outcomes than background factors such as consumer sentiment and fixed candidate attributes such as incumbency and partisan affiliation. ${ }^{170}$ If this view is correct, the partisan and demographic distribution of voters among states - a largely fortuitous circumstance - may matter more to the electoral college results than decisions about how and where to campaign. Even if one believes that shrewd campaigning can mitigate the risk of an electoral-popular split, it is hard to see why it is desirable for an electoral system to require candidates to focus on gaining narrow tactical advantages, a skill that bears little relation to governing and that, presumably, often comes at the expense of addressing the concerns of the electorate as a whole. The tactical emphasis the electoral college encourages is particularly problematic because, as the next Section describes, candidates may seek to gain an electoral college boost through such undesirable measures as suppressing or discouraging votes.

Thus, 2016 suggests that the popular-electoral split scenario remains a meaningful problem for the winner-take-all system - one that may occur more frequently, more arbitrarily, with more jarring popularelectoral disparities, and with more momentous consequences than has been thought possible in the past.

\section{Incentives for Fraud and Voter Suppression}

The pernicious effects of winner-take-all, however, go well beyond its potential to produce anomalous overall results. It has long been observed that winner-take-all creates little incentive on the part of campaigns to increase voter participation in states that are reliably red or blue, ${ }^{171}$ a reality that may account for the dramatically lower turnout in non-battleground versus battleground states. ${ }^{172}$ Perhaps even more importantly, however, winner-take-all provides a powerful incentive for campaigns to commit fraud in close states. ${ }^{173}$ This was certainly true in

that lack of campaign resources alone did not account for the electoral outcome).

170. See The Electoral Challenge: Theory Meets Practice ix (Stephen C. Craig \& David B. Hill, eds., 2011) ("Do campaigns really matter? A good bit of academic literature suggests that they do not - or at least not as much as politicians and the media tend to think they do.")

171. See Aвbотt \& Levine, supra note 6 , at 84 .

172. See KozA ET AL., supra note 3, at 37 (noting battleground states had an 11 percent higher voter turnout rate than the national average).

173. See Longley \& Braun, supra note 2, at 19 (explaining that winner-takeall "plac[es] a premium on fraud and accident"); ABBOTT \& LEVINE, supra note 6 , at 136 (arguing that direct election would decrease fraud because "it would eliminate the situation where large blocs of electoral votes hinged on how just a few popular votes were distributed"); Althouse, supra note 7, at 
the 1876 election, where "[i]n the casting, counting, and canvassing of votes there was every conceivable violation of the election laws," 174 including "riots, assassinations, murders, [and] midnight raids." ${ }^{175}$ While abuses were bipartisan and likely had a greater effect on depressing Hayes votes than Tilden votes ${ }^{176}$ they surely cast doubt on the final electoral college results, in which Hayes won four crucial states by less than 1100 votes. ${ }^{177}$

One would hope that today's election process is characterized by a greater degree of integrity. Yet some commentators have raised concerns about the potential for smaller-scale fraud today, noting the vulnerability of voting systems to tampering and the difficulty of auditing close races in some states. ${ }^{178}$ The disproportionate influence of particular groups in swing states makes elections more vulnerable to outside interference; in 2016, for example, Russian trolls may have targeted swing-state voters with false anti-Clinton news stories. ${ }^{179}$ Winner-take-all also magnifies the possibility that chance occurrences, such as bad weather in a reliably Democratic or Republican part of the state or confusing ballot design in one county, may tip the results arbitrarily into one column or the other. ${ }^{180}$

998 ("The unit rule magnifies the effect of fraud, and, consequently, heightens the temptation to engage in it.").

174. BEST, supra note 9 , at 53 .

175. Id. at 52 .

176. Id. at $52-53$.

177. See KozA ET AL., supra note 3, at 126.

178. See Zeynep Tufekci, The Election Won't Be Rigged. But It Could Be Hacked., N.Y. Times (Aug. 12, 2016), https://www.nytimes.com/2016/08/14/ opinion/campaign-stops/the-election-wont-be-rigged-but-it-could-be-hacked. html?_r=0 [https://perma.cc/9X2R-WVYX].

179. See Julian Borger, Investigators Explore If Russia Colluded with Pro-Trump Sites During US Election, GuARDIAN (July 5, 2017), https://www. theguardian.com/us-news/2017/jul/05/donald-trump-russia-investigationfake-news-hillary-clinton [https://perma.cc/3SF6-52ST].

180. A notable example of such a fortuitous occurrence was the use of the socalled "butterfly ballot" in Democratic-leaning Palm Beach County, Florida in 2000, widely believed to have confused voters into accidentally spoiling their ballot by double-voting. The number of votes that may have been affected substantially exceeded George W. Bush's eventual margin of victory in the state. See Fessenden, supra note 140 (noting that up to 5,310 Gore voters versus only 2,600 Bush voters may have accidentally spoiled their ballot in Palm Beach County). Similar problems disproportionately affected Gore voters in other parts of the state. See id. (noting similar problems in Duval County, Florida). See also Kathleen Bawn et al., A Theory of Political Parties: Groups, Policy Demands and Nominations in American Politics, 10 
Further, even where outright fraud does not occur, winner-take-all creates incentives to depress the votes of groups with a strong partisan affiliation-such as African-Americans ${ }^{181}$ or students ${ }^{182}$ - that might otherwise provide one's opponent's margin of victory. In 2016, for example, critics charged that Republicans in swing-state North Carolina passed restrictive voting legislation with the intent of making it more difficult for the overwhelmingly Democratic-leaning AfricanAmerican community to vote. ${ }^{183}$ The Fourth Circuit ultimately struck down the new state rules, but some county election boards continued to limit the availability of polling places and restrict early voting hours. ${ }^{184}$ While it is not entirely clear that such tactics are effective in reducing turnout, ${ }^{185}$ their use, as well as the clear incentive that winnertake-all provides to engage in them, is nonetheless troubling.

Winner-take-all may also be giving rise to new campaign strategies that focus on discouraging voters rather than motivating them. In 2016, a Trump campaign digital operation called Project Alamo barraged narrowly targeted groups of potential Clinton voters in swing states such as Florida with negative messages in order to discourage them from voting. ${ }^{186}$ A Trump campaign official boasted at the time that "[we]

PERSP. ON POL. 571, 577 (2012) (summarizing research that "uncontrollable events can have large effects" on election results).

181. See Vann R. Newkirk II, What Early Voting in North Carolina Actually Reveals, Atlantic (Nov. 8, 2016), https://www.theatlantic.com/politics/ archive/2016/11/north-carolina-early-voting/506963/ [https://perma.cc/SB R3-VLQ7]. The Fourth Circuit struck down provisions of North Carolina voting legislation that "restricted voting and registration in five different ways, all of which disproportionately affected African Americans." See N.C. State Conference of the NAACP v. McCrory, 831 F.3d 204, 214 (4th Cir. 2016). The court noted that "[v]oting in many areas of North Carolina is racially polarized," which left "minority voters uniquely vulnerable to the inevitable tendency of elected officials to entrench themselves by targeting groups unlikely to vote for them." Id. The measures in question, the court found, "target[ed] African Americans with almost surgical precision." Id.

182. See Elizabeth Campbell, Voting Hurdles Often Keep College Students Away from the Ballot Box, NBC NEws (Aug. 25, 2016), http://www.nbcnews. com/feature/college-game-plan/voting-hurdles-often-keep-college-studentsaway-ballot-box-n637046 [https://perma.cc/68WD-MCWH] (discussing, among other things, claims by a public policy professor that North Carolina enacted more stringent requirements for students in order to dampen the Democratic-leaning youth vote).

183. See Newkirk, supra note 181; see also McCrory, 831 F.3d at 214.

184. See Newkirk, supra note 181.

185. See $i d$. (noting the difficulty of distinguishing between new voting laws and historical disenfranchisement as the cause of low voter turnout).

186. See Joshua Green \& Sasha Issenberg, Inside the Trump Bunker, with Days to Go, Bloomberg Businessweek (Oct. 27, 2016, 6:00 AM), https://www. 
have three major voter suppression operations under way." 187 Messages were sent as so-called "dark posts"-nonpublic posts visible on Facebook only to those the campaign had selected - thus discouraging fact-checking or open dialogue. ${ }^{188}$ The tactic may have been a successful one, given that Trump won many of the targeted states by narrow margins. ${ }^{189}$ Nonetheless, rewarding this type of campaigning, as the winner-take-all system does, would seem to have few societal benefits. Indeed, following the 2016 election, commentators expressed concern about the use of Facebook to spread misleading or highly partisan information, cautioning that it might have the effect of increasing political polarization. ${ }^{190}$

The winner-take-all system thus creates troublesome incentives for candidates and parties. In extreme cases, the drive to eke out narrow victories has led to the sort of fraud and intimidation that occurred in 1876. But even less drastic tactics for depressing votes for one's opponent, such as reducing available polling places or providing voters with targeted negative content, have the potential to increase partisanship and lower civic engagement.

\section{Arbitrarily Distributing Power to Certain Voter Groups}

As the previous Section suggests, far from forcing candidates to campaign broadly, winner-takes-all rewards a campaign strategy that narrowly targets voters sufficient to form a majority in key states. Under a winner-take-all scheme, "a candidate can win an election by targeting only 25 percent of the national electorate -50 percent of the voters in states with 50 percent of the electoral votes." ${ }^{191}$ This risk is not merely theoretical; in every recent election, candidates have overwhelmingly concentrated resources in a handful of states. In 2012, for example, President Obama made post-convention campaign visits to only eight states, while Mitt Romney in the post-nomination period

bloomberg.com/news/articles/2016-10-27/inside-the-trump-bunker-with-12days-to-go [https://perma.cc/SR2C-8K8X].

187. Id.

188. Id.

189. See id. (explaining Trump's target states of Florida, Ohio, Pennsylvania, North Carolina, and Georgia); see also Leip, supra note 62 (indicating Trump's margin of victory in those states).

190. See, e.g., Olivia Solon, Facebook's Failure: Did Fake News and Polarized Politics Get Trump Elected?, GuARDIAN (Nov. 10, 2016, 5:59 PM), https://www.theguardian.com/technology/2016/nov/10/facebook-fake-newselection-conspiracy-theories [https://perma.cc/NPB4-D6C2].

191. Jide Nzelibe, The Fable of the Nationalist President and the Parochial Congress, 53 UCLA L. REV. 1217, 1234 (2006). 
campaigned in only ten. ${ }^{192}$ In thirty-eight states and the District of Columbia, neither candidate - and, for that matter, neither vicepresidential candidate - conducted a post-convention event. ${ }^{193}$ Nonbattleground states faced a similar dearth of campaign advertising ${ }^{194}$ and media coverage, including polling. ${ }^{195}$

This concentration of political attention sends a clear message to voters in the majority of states of their irrelevance, and it is perhaps unsurprising that turnout in the small minority of swing states significantly exceeds turnout in the rest of the country. ${ }^{196}$ At the same time, the intensity of the campaign may be more an annoyance than a boon to residents of contested states; every presidential election seems to feature news stories about people like the Pennsylvania resident interviewed in 2016, who reported that he disliked the nastiness of the campaign and had turned to Netflix to escape incessant political commercials. ${ }^{197}$ Yet battleground state residents also enjoy material advantages; some research has found that swing states receive more responsive disaster relief and additional federal grant dollars relative to states dominated by one party. ${ }^{198}$

Troublingly, there is some evidence that the number of swing states is shrinking, thus making the states in which the campaign is truly contested even more unrepresentative of the general U.S. population. The term "swing state" was not even in common use before the 1950 s $^{199}$

192. KOZA ET AL., supra note 3 , at 33 .

193. $I d$.

194. See id. at 12-32 (describing the concentration of campaign advertising and other resources in a few states during the 2004, 2008, and 2012 elections).

195. See id. at 33 .

196. In 2012, for example, turnout was 67 percent in battleground states and 59.4 percent in the nation on average. Id. at 37. In 2016, preliminary results suggested that turnout was similarly 65.3 percent in swing states and 56.3 in other states. Carl Bialik, Voter Turnout Fell, Especially in States That Clinton Won, FiveThirtyEight (Nov. 11, 2016, 6:22 PM), https:// fivethirtyeight.com/features/voter-turnout-fell-especially-in-states-thatclinton-won/ [https://perma.cc/4L39-Y9ZY]. These preliminary figures slightly understate overall 2016 turnout but nonetheless show a clear pattern. See id.

197. Emma Green, Pennsylvania Is Ready to Stop Being a Full-Time Swing State, Atlantic (Nov. 8, 2016), https://www.theatlantic.com/politics/ archive/2016/11/swing-state-pennsylvania-cant-wait-till-this-is-over/506909/ [https://perma.cc/EBL9-Q3G2].

198. See KozA ET AL., supra note 3, at 43-47 (summarizing research showing that highly-competitive states can expect to receive twice as many disaster declarations - triggering federal aid - than other states).

199. Lauren Leatherby \& Rich Harris, Swing States: How Changes in the Political Landscape Benefit Trump, GuARDIAN (Aug. 28, 2016, 12:00 AM), 
—its use tripled between 2000 and 2008 200 — and state allegiances shifted more freely in the past, making it less obvious which states would be in play. In the four elections between 1984 and 1996, for example, only seventeen states consistently voted for the same party; by contrast, in the four elections from 2000 to 2012, forty states did so. ${ }^{201}$ This trend means that winner-take-all is likely to result in the targeting of an evernarrowing pool of states and voters.

Winner-take-all does not only cause different states to be treated differently; it also results in disparate outcomes for groups of voters within a particular state. Winner-take-all has the effect of essentially rendering irrelevant both the excess majority votes of a candidate who carries a state by a wide margin and the votes for the runner-up candidate even if he or she has only fallen short by a handful of votes. While this effect as a whole has been criticized for lessening the impact of a variety of voters' preferences, ${ }^{202}$ some have argued that it has a particularly severe effect on members of racial or other minority groups. Matthew M. Hoffman, for example, has argued that "so long as minority voters have different political preferences than the majority - a fact that is almost self-evident in many parts of the country - their votes will be virtually meaningless in the final selection of the President." 203 This phenomenon, Hoffman argues, is of particular concern in the South, where the minority African-American population has consistently different presidential preferences from the majority white population that are never reflected in the allocation of electoral votes. ${ }^{204}$ Likewise, it has been argued that in predominantly urban states, the preferences of less-numerous rural voters are similarly shut out of the process through the operation of winner-takes-all. ${ }^{205}$

Finally, winner-takes-all confers immense power on an entirely arbitrary group of voters: swing voters in battleground states. There are of course various ways of assessing the power of a vote, and in for-

https://www.theguardian.com/us-news/2016/aug/28/swing-states-donaldtrump-republican-democrat-polarization [https://perma.cc/22W3-3PPD].

200. Id.

201. $I d$.

202. See, e.g., Аввотt \& Levine, supra note 6, at 56-57 (discussing the "wasted vote" phenomenon of winner-take-all).

203. Matthew M. Hoffman, The Illegitimate President: Minority Vote Dilution and the Electoral College, 105 YALE L.J. 935, 936 (1996).

204. See id. at 936-37. This outcome presents uncomfortable historical parallels to southern states' efforts to count disenfranchised slaves, and later freedmen, for purposes of representation while denying them the vote. See supra notes $73-81$ and accompanying text.

205. Debra Lyn Basset, The Politics of the Rural Vote, 35 ArIz. St. L.J. 743, 784 (2003). 
mal terms, these voters do not have any special status in contrast to, for example, the voters of Wyoming, who control more than three times more electoral votes per person than the voters of California. ${ }^{206}$ In practical terms, however, what is likely to matter to an individual voter is the chance that her vote will affect the ultimate national outcome - an analysis under which Wyoming residents are severely disadvantaged. A famous 1968 analysis by John F. Banzhaf III, ${ }^{207}$ which had considerable influence on the then-active congressional efforts at electoral college reform, ${ }^{208}$ emphasized the greater voting power of large-state residents, given their influence over a larger bloc of votes. ${ }^{209}$ As he concluded, "a voter in New York State has 3.312 times the voting power of a citizen in another part of the country." ${ }^{210}$ Banzhaf, however, considered only the voting power inherent in a winner-take-all system; as he acknowledged, a voter's "actual ability to affect the outcome of any particular election" would depend on contingent factors such as "the political impotence of a Republican in a solidly Democratic state." 211 More recently, Andrew Gelman has modeled the chance that a single vote will determine the outcome while taking into account some such realworld factors, including state-by-state polling data. ${ }^{212}$ In an analysis published just prior to the 2016 election, he concluded that voting power would be greatest - approximately one in one million probability of an individual vote affecting the result-in New Hampshire and Colorado, and orders of magnitude lower in both California, with a one in seven billion chance, and Wyoming, with a one in thirty billion chance. ${ }^{213}$ To put it another way, a New Hampshire resident has 30,000

206. See KozA ET AL., supra note 3, at 56 n.114.

207. John F. Banzhaf III, One Man, 3.312 Votes: A Mathematical Analysis of the Electoral College, 13 ViLL. L. REv. 304, 306 (1968).

208. See Althouse, supra note 7, at 1000 n.40.

209. Banzhaf, supra note 207, at 324-25.

210. Id. at 306 .

211. Id. at 308. Banzhaf argued - somewhat uncompellingly - that ignoring such real-world factors allowed for focus on the system's inherent fairness. See id. For an extensive critique of Banzhaf's methodology, arguing that by assuming all votes are random and independent of each other, Banzhaf "make[s] voters in large jurisdictions appear more powerful than they really are," see Andrew Gelman et al., Standard Voting Power Indexes Do Not Work: An Empirical Analysis, 34 BRITish J. PoL. SCI. 657, 657 (2004).

212. See Andrew Gelman et al., What Is the Probability Your Vote Will Make a Difference?, 50 ECON. INQUIRY 321, 322 (2012).

213. See Andrew Gelman, What Are the Chances Your Vote Matters?, Slate (Nov. 7, 2016, 5:40 PM), http://www.slate.com/articles/news_and politics/politics/2016/11/here_are_the_chances_your_vote_matters.html [https://perma.cc/39XD-YWE9]. Wyoming is tied with Oklahoma for the lowest potential impact. Id. See also Pierre-Antoine Kremp \& Andrew 
times more power over the result than a citizen of Wyoming, making campaign efforts to sway the New Hampshire voter considerably more valuable. ${ }^{214}$ Even if imperfect polling data renders these figures necessarily imprecise, they nonetheless illustrate the scale of the disparities.

Such disparities would be troubling on fairness grounds even if there were some reason to believe that swing voters in New Hampshire were likely to exercise better judgment than reliably Republican or Democratic voters in "safe" states like Wyoming and California. In fact, however, abundant research suggests that many swing voters are politically naïve and uninformed and that low-information voters are more likely to be undecided between candidates. ${ }^{215}$ Thus, the disproportionate influence of these voters, it can be argued, lacks logic as well as fairness.

\section{Distortions of the Meaning of an Election}

As some commentators have argued, another troubling feature of the winner-take-all system is its potential to create "false mandates"216 - electoral-vote results that suggest a more decisive win than is reflected in the popular vote. ${ }^{217}$ This effect may convert a decisive but hardly overwhelming popular-vote margin, such as George H.W. Bush's in 1988, into an electoral college blowout, ${ }^{218}$ or grant a 43 percent plurality winner, such as Bill Clinton in 1992, a decisive electoral margin of $370-168$, or 69 to 31 percent. ${ }^{219}$ This effect occurs within

Gelman, What Is the Chance That Your Vote Will Decide the Election?, https://pkremp.github.io/pr_decisive_vote.html [https://perma.cc/66AR -M2SF].

214. Importantly, Gelman's analysis applies not just to individuals but to groups of voters; in other words, states in which an individual vote matters most are also states in which "a swing of 100 or 1,000 votes" is most likely to matter. See Gelman, supra note 212, at 323.

215. See Bawn et al., supra note 180, at 577 (noting that "many . . . swing voters . . . know dramatically little about politics"). See also Thomas R. Palfrey \& Keith T. Poole, The Relationship Between Information, Ideology, and Voting Behavior, 31 Am. J. POL. SCI. 511, 530 (1987) (finding that higher levels of voter information are positively correlated with political polarization and negatively correlated with "indifference between candidates").

216. Аввотt \& Levine, supra note 6 , at 5.

217. See id. at 101-02, 109 (arguing that the electoral college often "augment $[\mathrm{s}]$... a meager win into a thundering triumph," and is thus "much kinder to winning presidential candidates than the voters have been").

218. See id. at 109 (explaining that, outside the South, the popular vote was split fairly evenly between Bush and opponent Dukakis, but Bush won almost 80 percent of the electoral votes).

219. See Leip, supra note 62. 
individual states as well: winner-take-all not only enables one candidate to amass all a state's electoral votes with a minuscule margin of victory, such as George W. Bush's 537-vote Florida win in $2000,{ }^{220}$ but also makes it possible for one candidate to win a state with "breathtaking[ly]" low pluralities, such as George H.W. Bush's attainment of Arizona's eight electoral votes in 1992 with only a 38.5 percent plurality. ${ }^{221}$

This tendency is sometimes cited as a positive feature by the electoral college's defenders, who argue that the appearance of a mandate enhances the victor's legitimacy and thus permits narrow winners more scope to govern effectively. ${ }^{222}$ Yet it is far from clear that creating a disconnect between the realities of popular sentiment and the message conveyed by the electoral college totals is always, or even frequently, an affirmative good. Negative effects are also possible: The magnification of the president's victory, for example, may cause him to misread the will of the electorate and support unpopular or even autocratic policies. ${ }^{223}$ The creation of a false mandate may contribute to a bitter political climate, making defeat harder on the losers. ${ }^{224}$ Further, there is no guarantee that the electoral losers will accept the alleged mandate-

220. See id.

221. See Longley \& Peirce, supra note 108, at 137.

222. See BiCKel, supra note 158, at 31 ("For in the electoral college, a narrow popular victory is perceived through a magnifying glass. Even if it should put a narrow loser in office, the electoral college would probably ensure greater acceptance for him than the winner by a very small margin could expect in a system of direct popular election.") See also Paul Boudreaux, The Electoral College and Its Meager Federalism, 88 MARQ. L. REv. 195, 216 (2004) ("Some supporters of the electoral college . . . assume that the indirect [i.e., electoral] vote consistently makes the margin of victory wider and that a wider margin appears more legitimate."). As Boudreaux notes, however, both these assumptions are faulty; electoral margins of victory are not always larger than popular ones, and large electoral victories in hardfought elections do not necessarily enhance legitimacy. See id. at 218-19.

223. See Aввотt \& Levine, supra note 6, at 108-09 (observing that "presidents who believe that the country overwhelmingly supported them (when it did not) may be tempted to act autocratically"). It is notable that Abbott and Levine made these observations in 1991, when political partisanship was lower and constraints on presidential authority greater than they are today; presumably, today's fiercer party divides and broader executive power only magnify these possibilities. See Niraj Chokshi, U.S. Partisanship Is Highest in Decades, Pew Study Finds, N.Y. Times (June 23, 2016), https://www. nytimes.com/2016/06/24/us/politics/partisanship-republicans-democratspew-research.html?_r=0 [https://perma.cc/L8BK-J56H]; Alberto R. Gonzales, Advising the President: The Growing Scope of Executive Power to Protect America, 38 Harv. J.L. \& Pub. PoL'Y 451, 506-07 (2015).

224. See Aввотт \& Levine, supra note 6, at 110 (observing that "[l]osing is losing, but the electoral college results really rub it in."). 
conferring magic of the electoral college. Following the 1992 election, for example, Republicans railed against Bill Clinton as a plurality president who had won just 43 percent of the vote, notwithstanding his decisive electoral majority. ${ }^{225}$ Far from rallying public support around the winner, the magnification effect of the electoral college may, on the contrary, increase partisan tensions by emboldening winners while making losers feel unrepresented or ignored.

\section{Third-Party Mischief and Spoiler Effects}

Some commentators have argued that winner-take-all strengthens the two-party system because it is difficult for a more peripheral candidate, even if he or she has some support, to attain a plurality in any one state. ${ }^{226}$ Even if this were true - and it is an obstacle that, at least historically, some third-party candidates have overcome - third-party candidates and their supporters have the potential both to cause great trouble under a winner-take-all system and to be arbitrarily disadvantaged by it.

While it has proven essentially impossible for a candidate not from a major party to win a presidential election and difficult for such a candidate to win a state, such candidates can easily serve as spoilers, drawing enough votes from one candidate to deliver a state to another. ${ }^{227}$ This gives third-party partisans in swing states influence over major-party candidates and their positions that may be entirely unwarranted by their modest numbers. It also forces third-party voters, at least in closely contested states, to think strategically when they vote: should they vote for their preferred candidate, perhaps allowing their least favored candidate to win, or should they vote for the "lesser of two evils" among the major-party candidates? Support for alternative voting systems, such as instant runoff, among third-party enthusiasts strongly suggests that this is a choice that voters would prefer not to have to make, ${ }^{228}$ and it is one they would generally not be re-

225. Andrés Martinez, Americans Have Seen the Last Four Presidents as Illegitimate. Here's Why., WAsh. Post (Jan. 20, 2017), https://www. washingtonpost.com/posteverything/wp/2017/01/20/americans-have-seenthe-last-four-presidents-as-illegitimate-heres-why/?utm_term $=.1532 \mathrm{bf59ccf4}$ [https://perma.cc/3KH9-K4US].

226. See, e.g., Althouse, supra note 7, at 1005 ("Although the electoral college does not eliminate third parties, it suppresses them.").

227. See Aвbott \& Levine, supra note 6, at 110-11 (discussing the candidacy of John Anderson as an example of this phenomenon). The third-party spoiler phenomenon has only come into greater focus in the succeeding years.

228. See Alexander Keyssar, The Right to Vote: The Contested History of Democracy in the United States 437 n.16 (rev. ed. 2009) (noting that instant runoff would avoid forcing third-party voters to confront 
quired to make in a direct election or proportional allocation system, in which their third-party preferences would be far less consequential.

Historically, winner-take-all has also provided more sinister opportunities for election gamesmanship by third parties. Throughout the civil rights era, segregationist third parties with strong regional support repeatedly attempted to use the electoral college to increase their power; their plan was to accrue enough electoral votes to be necessary for electoral college victory and to force concessions from the majority vote winner in return for their support. ${ }^{229}$ Although this scheme was never fully successful, it likely succeeded in making some national-party candidates more receptive to segregationists' concerns. ${ }^{230}$ Further, there is no guarantee that a similar scenario will not resurface in the future. For example, former CIA officer Evan McMullin, running as a conservative alternative to Donald Trump in 2016, concentrated his campaign in Utah, in part with the hope of depriving both major-party candidates of an electoral college majority and throwing the election into the House of Representatives. ${ }^{231}$ Although McMullin did not succeed in winning the state - and the results of the election would not have changed even if he had - he ran only a few points behind second-place candidate Hillary Clinton, ${ }^{232}$ and might have done still better had his national profile been higher to begin with. As it was, McMullin's share of the vote in Utah was approximately 40 times his national vote percentage, ${ }^{233}$ thus illustrating the potential for a third-party candidate to find disproportionate favor in a single state or region.

Thus, far from discouraging third parties entirely, the electoral college provides opportunities for third-party supporters to exercise leverage disproportionate to their numbers and for third-party candi-

"the classic dilemma of having to choose between 'wasting their votes' or voting for the "lesser of two evils"').

229. See Hoffman, supra note 203, at 950-62; see also LONGLEy \& PeIRCE, supra note 108, at 64 (discussing how the winner-take-all system magnified George Wallace's influence by his "ability to draw off votes from one of the two major parties and possibly tilt a large state's bloc of . . . electoral votes"); LONGLEY \& BRAUn, supra note 2, at 9 (noting that the unit rule "favors third parties with a sectional orientation, and . . . discriminates against those with a national orientation").

230. See Hoffman, supra note 203, at 957 (noting that Nixon "would take to heart" the relative success of segregationist candidate Harry F. Byrd in 1960 when crafting his strategy in 1968).

231. See Melanie Mason, Evan McMullin Made Utah a Presidential Battleground. Next, He'll Try To Transform Conservative Politics, L.A. Times (Oct. 27, 2016, 3:00 AM), http://www.latimes.com/politics/la-na-pol-evan-mcmullinutah-20161027-story.html [https://perma.cc/6UFW-8QQN].

232. See Leip, supra note 62 .

233. See id. 
dates to run up votes in one state or region in order to maximize their influence in the electoral college. Further, both effects are highly problematic. As is true with other voter groups, the influence of thirdparty voters is arbitrarily distributed; Green Party supporters in swingstate Florida have tremendous leverage while libertarians in safely Democratic California have none. Similarly, it is hard to see what is to be gained from the phenomenon of third-party kingmakers who use regional support either to undermine or to pressure major-party candidates; such a scenario at best invites chaos and at worst allows the sort of mischief in which George Wallace and other segregationist candidates attempted to engage. ${ }^{234}$ It is questionable, therefore, whether winnertake-all does much to shore up the two-party system relative to alternatives that also include measures that make it more difficult for third parties to gain support. ${ }^{235}$ Even if winner-take-all helps the major parties to some degree, this effect must be weighed against the potential third-party gamesmanship it may allow.

\section{B. The Experience of Winner-Take-All in Party Nominations}

The preceding section has argued that the winner-take-all system has introduced a variety of pernicious effects into U.S. presidential elections. Interestingly, winner-take-all has also been used in another aspect of U.S. politics: the system of delegate allocation used in the process of selecting party nominees. It is notable that, in that context, the rule has come in for substantial criticism. Indeed, beliefs that the "unit rule" was an undemocratic mechanism led the Democratic Party to forbid the use of winner-take-all delegate contests in $1968 .{ }^{236}$ While Republican Party continues to allow some states to hold winner-take-all contests, it has restricted them to some degree, and many observers argued that the continuing use of winner-take-all primaries had negative effects in the selection process for the 2016 Republican nominee. ${ }^{237}$

\section{Winner-Take-All in the Evolution of Modern Primaries}

While the first presidential nomination primaries date from the early twentieth century, the idea that party nominees should be chosen democratically rather than by party insiders did not really take hold until after the controversial Democratic nomination process of $1968 .{ }^{238}$

234. See supra note 229 and accompanying text.

235. Direct election, for example, could include a runoff mechanism, while a fractional proportional approach could discourage third-party candidates by setting a threshold percentage for receiving electoral votes.

236. See infra note 242 and accompanying text.

237. See infra notes 251-261 and accompanying text.

238. See Lonna Rae Atkeson \& Cherie D. Maestas, Meaningful Participation and the Evolution of the Reformed Presidential Nominating System, 42 PS: PoL. 
Under the ensuing reforms - which began with the Democrats, but soon took hold in the Republican Party as well ${ }^{239}$ — states increasingly began binding delegates to vote for the winner of popular primaries, with caucuses assuming a secondary role. ${ }^{240}$

As part of the reform process, the Democratic Party moved early to forbid the use of winner-take-all contests. At the 1968 Democratic National Convention, delegates - with the support of nominee Humphrey - voted to abolish the "unit rule," ${ }^{241}$ and subsequent reforms forbade the use of winner-take-all in the nominating process. ${ }^{242}$ The move to proportional representation was part of the general democratizing trend, under which delegate allocation would be linked more directly to popular support in the states, ${ }^{243}$ and was founded on the belief that winner-take-all allocation did not accurately reflect the voters' choices ${ }^{244}$ and stifled the influence of minority and youth voters in particular. ${ }^{245}$

Currently, the Democratic Party employs a rule under which popularly chosen delegates are allocated proportionately to candidates who

SCI. \& POL. 59, 59 (2009) ("The disastrous 1968 convention spawned a cascade of reforms in the presidential nomination system, many of which were intended to create greater opportunity for meaningful participation of the party's rank-and-file members."); see also MARTy COHEn ET AL., ThE Party Decides: Presidential Nominations Before and After REFORM 1-2 (2008) (noting that nominee Hubert Humphrey "did not contest a single primary" and that outrage over his nomination sparked reform efforts).

239. See COHEN ET AL., supra note 238, at 2.

240. See Zachary M. Bluestone, Note, The Unscripted Evolution of Presidential Nominations: From Founding-Era Idealism to the Dominance of Party Primaries, 39 Harv. J.L. \& PUB. Pol'y 963, 988 (2016) (discussing how as a result of new incentives to hold primaries rather than caucuses, "[i]n 1968, sixteen states held primaries, but that number was up to thirty by 1976").

241. See id. at 985 .

242. See C.F.W., One Man-One Vote in the Selection of Presidential Nominating Delegates by State Party Conventions, 5 U. Rich. L. Rev. 349, 362 n.72 (1971).

243. See Atkeson \& Maestas, supra note 238, at 59.

244. See Robert E. DiClerico \& James W. Davis, Choosing Our Choices: Debating the Presidential Nominating Process 10 (2000) (noting that the McGovern-Frasier Commission, which was tasked with making reform recommendations in the wake of the 1968 nomination furor, believed that the unit rule "prevented a fair reflection of voter preferences").

245. See Jeffrey L. Pressman \& Denis G. Sullivan, Convention Reform and Conventional Wisdom: An Empirical Assessment of Democratic Party Reforms, 89 PoL. SCI. Q. 539, 539-40 (1974). 
pass a 15 percent popular vote threshold. ${ }^{246}$ An additional number of "superdelegates" have historically been chosen from the ranks of party officials and have not been pledged to any particular candidate, permitting them to vote their own preferences instead. ${ }^{247}$ This practice will change in 2020, when the majority of superdelegates will be bound to primary and caucus results. ${ }^{248}$ While some rounding necessarily occurs in the delegate allocation process, ${ }^{249}$ it should be noted that the Democratic Party makes use of several times more delegates than there are electors, ${ }^{250}$ thus allowing the allocation of delegates to mirror the popular vote percentage somewhat more precisely.

By contrast, the Republican Party, even as it adopted most of the same reforms as the Democratic Party, decided to retain winner-takeall contests in many states, ${ }^{251}$ reflecting a longstanding Republican view that the nominating process should be "designed to build consensus behind a candidate who wins and keeps winning." ${ }^{252}$ The current system features a mix of proportional, winner-take-all, and modified winner-

246. Joshua T. Putnam, Rules Changes and the 2016 Presidential Nominations, 53 SoC'y 493, 494 (2016).

247. See James A. Barnes \& Jerrick Adams, 2016 Presidential Nominations: Calendar and Delegate Rules, BALlotPedia, https://ballotpedia.org/2016 presidential_nominations:_calendar_and_delegate_rules [https://perma. cc/FML6-HETK].

248. See David Weigel, Democrats Vote to Bind Most Superdelegates to State Primary Results, WAsh. Post (July 23, 2016), https://www. washingtonpost.com/news/postpolitics/wp/2016/07/23/democrats-vote-tobind-most-superdelegates-to-state-primary-results/?utm_term $=.5 \mathrm{bc} 21 \mathrm{aa} 64$ 403 [https://perma.cc/LDV7-7HE4] (noting that "roughly two-thirds" of superdelegates will be restricted).

249. See Democratic National Committee, Call For the 2016 Democratic National Convention 1, 1 (Dec. 15, 2014), http://demrulz.org/wp-content/ files/12.15.14_2016_Delegate_Selection_Documents_Mailing_Rules_C all_Regs_Model_Plan_Checklist_12.15.14.pdf [https://perma.cc/9LNUGN2R].

250. The delegate pool each state is allotted is determined according to a complicated formula that takes into account both population, as reflected in the state's electoral votes, and past support for Democratic candidates, among other factors. See $i d$. at 1-3. California, for example, had 475 pledged delegates and 75 superdelegates, for a total of 550-ten times more than its electoral vote total of 55. See BALlotPEDiA, Democratic National Convention, 2016, https://ballotpedia.org/Democratic_National_Conven tion,_2016 [https://perma.cc/8BZ4-KR2M] (last visited Sept. 29, 2017).

251. See Thomas R. Marshall, Caucuses and Primaries: Measuring Reform in the Presidential Nomination Process, 7 Am. Pol. Q. 155, 164 (1979).

252. Putnam, supra note 246 , at 496. 
take-all contests; ${ }^{253}$ states that opt to hold earlier contests are generally required to incorporate an element of proportionality, although they can award at-large or bonus delegates on a winner-take-all basis, while states that wait until the "proportionality window" has passed can allocate delegates in any way they choose. ${ }^{254}$

Prior to the 2016 election, the Republican National Committeebelieving that a prolonged nomination struggle had weakened Mitt Romney's candidacy in 2012 - shortened the window in which states were required to hold proportional contests in an effort to speed up the process. ${ }^{255}$ This use of winner-take-all, like other features of the Republican nominating process, was thus intended to minimize intraparty friction by creating an early frontrunner, one who presumably would be the choice of the party establishment, and maximizing that person's early lead, reducing the prospects of challengers and discouraging them from continuing in the race. ${ }^{256}$

This rationale for winner-take-all, however, backfired spectacularly in 2016, when Donald Trump was able to translate plurality wins in winner-take-all contests into huge delegate gains despite the opposition of the Republican Party establishment as well as, in many cases, a majority of Republican primary voters. In Florida, for example, candidate Trump won all ninety-nine of the state's delegates despite

253. See Michael T. Morley, Reforming the Contested Convention: Rethinking the Presidential Nomination Process, 85 Fordham L. Rev. 1073, 1085 (2016) (describing Republican mix of methods including winner-take-all, proportional, and systems in which "a candidate who wins more than a certain percentage of the statewide vote (typically, a majority) receives all of that state's delegates; if no candidate reaches that threshold, delegates are awarded proportionally"). Some states also use a mix of district-based allocation plus an award of statewide delegates to the primary winner. See $i d$.

254. See Josh Putnam, Everything You Need to Know About How the Presidential Primary Works, WAsH. POST (May 12, 2015), https://www.washingtonpost. com/news/monkey-cage/wp/2015/05/12/everything-you-need-to-knowabout-how-the-presidential-primary-works/ [https://perma.cc/WP3P-C7Q3].

255. Id. The proportionality window was shortened to just two weeks. Putnam notes, however, that even as the Republican party diminished the importance of proportional contests, it also imposed stricter requirements for what constitutes a proportional primary. $I d$.

256. See Travis Rideout et al., Following the Rules? Candidate Strategy in Presidential Primaries, 90 Soc. SCI. Q. 777, 778 (2009) (suggesting that a mostly proportional system, like that used by the Democratic Party, is likely to result in a "more protracted race to nomination," as it did in 2008, while the greater Republican reliance on winner-take-all produces an earlier frontrunner); see also Joshua T. Putnam, The Impact of Rule Changes on the 2012 Republican Presidential Primary Process, 49 SoC'y 400, 403 (2012) (suggesting that a switch to more proportionality tends to result in a slower process of delegate accumulation). 
garnering only 45.7 percent of the vote. ${ }^{257}$ Shortly before the Florida primary, a Trump adviser described such winner-take-all contests as the "rocket fuel" that would propel the candidate to unstoppable victory. ${ }^{258}$ This proved to be an accurate view of how the vote played out in practice; through success in winner-take-all states, Trump was able to amass a significantly larger percentage of the delegate count than the popular vote. ${ }^{259}$ Observers noted that Trump would have likely failed to attain a majority of pledged delegates under Democratic Party primary rules, ${ }^{260}$ and that the post-2012 changes to the Republican process designed to further advantage the front-runner had helped to "advance[] that air of inevitability forming around Donald Trump." 261

257. Florida Primary Results, N.Y. Times (Sept. 29, 2016, 10:37 AM), https://www.nytimes.com/elections/2016/results/primaries/florida [https: //perma.cc/Y5L7-DTWA].

258. Trip Gabriel, Republican Delegate Math Favors Donald Trump After Latest Wins, N.Y. Times (Mar. 10, 2017), https://www.nytimes.com/2016/03/ 10/us/politics/donald-trump-delegates.html?_r $=0 \quad$ [https://perma.cc/58A A-K568].

259. In mid-April 2016, for example, Trump had won 48 percent of the delegates in the 35 contests that had taken place up to that point, while winning only 37 percent of the vote. See Harry Enten, Trump's Right that the GOP Primary Is Unfair - It Favors Him, FiveThintyEight (Apr. 14, 2016, 7:01 AM), https://fivethirtyeight.com/features/trumps-right-that-the-gop-primary -is-unfair-it-favors-him/ [https://perma.cc/GQ46-UH7F] (showing that Trump won 47.6 percent of the delegate count, but only 37 percent of the popular vote).

260. See, e.g., Nate Silver, Donald Trump Would Be Easy to Stop Under Democratic Rules, FiveThiRTyEight (Mar. 7, 2016, 12:21 PM), https:// fivethirtyeight.com/features/donald-trump-would-be-easy-to-stop-underdemocratic-rules/ [https://perma.cc/PHY2-MRQK] (arguing that "[i]f the Republican nomination were contested under Democratic delegate rules instead, Trump would find it almost impossible to get a majority of delegates"); Michael Barone, Republicans Should Have Adopted Democrats' Rules-And Vice Versa, WAsh. ExAminer (May 1, 2016, 5:00 PM), http://www.washingtonexaminer.com/republicans-should-have-adopted-dem ocrats-rules-and-vice-versa/article/2589998 [https://perma.cc/H85R-SMBU] (noting that under proportional rules, Trump would have hundreds fewer delegates and would likely be unable to attain a majority). Ultimately, going into the Republican National Convention, Trump had less than 45 percent of the popular vote, but had garnered more than 58 percent of the pledged delegates. On the convention floor, he ultimately received nearly 70 percent of the delegates' support. Richard E. Berg-Andersson, Presidential Primaries, Caucuses, and Conventions: Republican Convention, GREEN PAPERs, http:// www.thegreenpapers.com/P16/R [https://perma.cc/B7JZ-2BUL] (last modified Aug. 20, 2016).

261. Kevin Uhrmacher et al., Republicans Adjusted Rules for Their Primaries After 2012, and It's Helping Trump, WASH. Post (Mar. 9, 2016), https:// www.washingtonpost.com/graphics/politics/2016election/primaries/explain ing-the-presidential-primary-process / [https://perma.cc/C7MB-YAPD] 


\section{Conclusions from Winner-Take-All in Party Primaries}

What to make of this historical experience? On the one hand, it has been argued that the use of winner-take-all contests worked well for the Republican Party prior to 2016 in avoiding dissension, and that the Democrats' process has too often resulted in a prolonged and harmful struggle for the nomination. ${ }^{262}$ The Democratic Party process has also been plagued by an inability to winnow marginal candidates until well into the nominating season - a phenomenon that may or may not be relevant to national elections. ${ }^{263}$ On the other hand, proportional primary systems appear to produce nominees with broader support than those chosen through winner-take-all delegate allocation ${ }^{264}$ and to induce candidates to spend resources in a greater number of states. ${ }^{265}$

Further, any comparative look at the two systems has to confront the role that winner-take-all played in the nomination of Donald Trump, who was able to use a divided Republican opposition to convert pluralities into massive delegate yields despite the opposition of the party establishment and a majority of Republican primary voters. ${ }^{266}$ The 2016 Republican nomination process thus illustrates one of the ways in which winner-take-all can produce results at odds with popular sentiment. It also suggests that such effects can be magnified through the false mandates that winner-take-all can create - allowing a candi-

("Much to the dismay of some Republicans, the party's primary process is working just as intended. Designed to choose a nominee quickly, this year's rules have advanced that air of inevitability forming around Donald Trump, who has won 15 of the first 24 contests.").

262. See Wayne P. Steger, Who Wins Nominations and Why?: An Updated Forecast of the Presidential Primary Vote, 60 PoL. Res. Q. 91, 92 (2007) ("Democratic nominations are divisive because the party electorate is divided, whereas the Republican electorate rallies around a front-runner early and sticks with that candidate through the primaries.").

263. See Wayne P. Steger et al., Candidate Competition and Attrition in Presidential Primaries, 1912-2000, 30 Amer. Pol. Res. 528, 548 (2002) (noting that the Republican Party's winner-take-all rules "more efficiently drive out marginal candidates"). Note, however, that the tendency of Republicans to coalesce around an early front-runner predates the reform era, suggesting that other causes may be at play. See $i d$.

264. Barbara Norrander, Presidential Nomination Politics in the Post-Reform Era, 49 PoL. REs. Q. 875, 877 (1996). See also Barone, supra note 260.

265. See Norrander, supra note 264, at 879 (noting that "if proportional representation rules are employed, . . . it makes sense for the disadvantaged candidate to spend a few dollars in hopes of winning some delegates"); see also Rideout et al., supra note 256, at 790 ("There is some evidence, ... . which suggests that frontrunners make more visits, all else equal, to winner-take-all states than do long-shot candidates.").

266. See supra notes 260-261 and accompanying text. 
date to amass significant victories that provide a misleading indicator of his level of popular support.

There are of course numerous differences between the party nominating contests and the general election. Nominating contests are staggered and take place over several months; rules, such as whether delegates are selected by primary or by caucus, vary significantly from state to state; many serious candidates may be involved in contrast to the two-party contests that characterize the general election, and so forth. ${ }^{267}$ Indeed, the many variables involved, including "delegate distribution rules, delegate apportionment among the states, primary sequencing, regional support for candidates, ideological crowding of candidate fields, and campaign finance rules" have made it difficult for researchers to isolate the effects of any particular factor, including the use of winner-take-all or other sorts of delegate selection rules. ${ }^{268}$ Nonetheless, the parties' recent experiences suggest that proportional representation, despite some disadvantages, is both a more accurate reflection of voter sentiment and a more effective block against the selection of candidates who enjoy only narrow plurality support.

\section{Implications for Electoral College Reform}

This Article has argued that, among the various controversial features of the electoral college, its de facto incorporation of a winnertake-all system stands out as uniquely indefensible. Unlike the other ways in which the electoral college diverges from strict popular preference, the winner-take-all system evolved haphazardly as the result of state responses to immediate individual incentives, not as a product of deliberation and compromise. Further, despite the lack of forethought or intentionality in the establishment of a winner-take-all system, winner-take-all allocation remains by far the strongest driver of differences between popular and electoral margins. ${ }^{269}$ Finally, the problems created by winner-take-all are not limited to the possibility of producing an electoral winner who falls short in the popular vote. Rather, winnertake-all contributes several additional ills to the electoral process by creating heightened incentives to commit voter fraud, disproportionately rewarding the suppression of votes, distorting the expressive value of the popular vote, and inviting third-party mischief. The following Section argues that, as a result, focus on the problems of winner-takeall should occupy a more central place in criticism of the electoral college and proposals for alternatives.

267. Norrander, supra note 264 , at $876-77$.

268. See id. at 876 .

269. See Aввотt \& Levine, supra note 6 , at 21. 


\section{A. The Underemphasis of Winner-Take-All in Electoral College Critiques}

On the whole, the distinctive effects of the winner-take-all system have been underemphasized in criticism of the electoral college. Calls to reform or replace the electoral college have, instead, tended to lump the undemocratic features of the electoral college together to argue for their replacement in one fell swoop, generally with a system of direct popular election of the president. ${ }^{270}$ Such critiques have often rejected alternatives to winner-take-all, such as allocating electoral votes proportionately, because they fail to address the other ways in which the electoral college promotes outcomes that diverge from the popular vote. ${ }^{271}$

To some extent, these arguments have a point-direct popular election of the president would not only eliminate the problems created by winner-take-all but is likely the best way of doing so. Direct election is much simpler to grasp than a complex system of proportional allocation, and may be more readily explained to Congress, state legislatures, or the general public. ${ }^{272}$ It would avoid the many intricacies of a proportional-vote scheme that would otherwise have to be resolved, such as how to handle fractional votes, what to do about ties or nearties, and whether and how to rein in third parties. Under the National Popular Vote Compact, direct election could potentially be effected gradually by the decisions of individual states; by contrast, proportional allocation of electoral votes at the state level provides opportunities for partisan mischief if done on a piecemeal basis, ${ }^{273}$ meaning that any reform would have to occur through constitutional amendment to avoid unfairly advantaging one party.

270. See KOZA ET AL., supra note 3, at 155 (arguing that, of various reform proposals, only direct election would remedy all electoral college deficiencies).

271. See id. at 135 (acknowledging that a fractional proportional approach would make more voters' preferences relevant, but rejecting it on the grounds that it would still fail to count every vote equally); Аввотт \& LEvine, supra note 6 , at 122-23 (rejecting proportional allocation because it would continue to give a relative advantage to small and low-turnout states).

272. See Aввотт \& Levine, supra note 6, at 132 ("The elegance of direct election is its simplicity.").

273. See, e.g., Tom Cohen, Some GOP-led States Look at Electoral Vote Changes, CNN (Jan. 25, 2013), http://www.cnn.com/2013/01/25/politics/electoralcollege/index.html (describing efforts by Republicans with a "partisan motive" to eliminate winner-take-all in states such as Virginia that have tended to vote Democratic in presidential contests). See also KozA ET AL., supra note 3 , at 683 (detailing numerous problems with adopting the proportional approach on a piecemeal basis, including slowly increasing the influence of states that retained the winner-take-all model). 
Further, there is much to be said in favor of eliminating the electoral college's other counter-majoritarian features. The two-vote bonus can be seen as an ineffective half-measure that fails in practice to protect the interests of small states - there is little evidence, for example, that presidential candidates campaign frequently in small states or are particularly attentive to their interests - while nonetheless threatening to produce electoral-popular divergence, as likely occurred in $2000 .{ }^{274}$ Likewise, the allocation of electoral votes based on population remains suspect for its historical roots in slavery and the disenfranchisement of blacks and women ${ }^{275}$ and arguably creates inadequate incentives for states to extend the franchise broadly - as through, for example, automatic voter registration - or for parties and candidates to focus on turnout. ${ }^{276}$ Thus, it is understandable to some degree why proposals for electoral college reform do not single out winner-take-all for criticism: their preferred solution of direct election would eliminate the problems winner-take-all creates, while bringing about additional benefits.

Despite these arguments, however, there is a strong case that proposals to reform the electoral college have directed inadequate fire toward the winner-take-all system in particular. Both philosophical and pragmatic reasons exist for advocates of electoral college alternatives to make the deficiencies of winner-take-all their central critique and abolishing winner-take-all their principal goal. Because a switch to direct popular election of the president may be the most feasible way of eliminating winner-take-all, this shift in focus may entail only a modest change in current messaging. At the same time, however, electoral college reform advocates should be open, under the appropriate circumstances, to supporting alternative proposals, such as proportional or bonus schemes, that eliminate or dilute winner-take-all while preserving some features of the current electoral college.

\section{B. The Case That Winner-Take-All Is the Electoral College's Worst} Feature

The philosophical case for focusing on winner-take-all rests on the fact that the harm it does to U.S politics is both serious and multifaceted, and the arguments made in its defense are commensurately

274. See supra note 136 and accompanying text. Moreover, Gore would probably not have won the electoral vote under a fractional proportional approach. See KozA ET AL., supra note 3, at 135 (finding that Gore would have received half an electoral vote less than Bush under at least one iteration of the fractional proportional approach).

275. See, e.g., Stern, supra note 33.

276. See ABbott \& Levine, supra note 6, at 123 ("Even under proportionality, popular votes in high-turnout states would get discounted and popular votes in low-turnout states would get inflated - thus contributing to the possibility of a wrong winner outcome."). 
weak. The possibility of an electoral-popular split has long been viewed as the greatest harm the electoral college has the potential to cause, and winner-take-all allocation currently contributes most strongly to the risk of that outcome. ${ }^{277}$ As the previous Section discussed, however, winner-take-all has many deficiencies beyond its potential to distort the popular vote, from the incentives it provides for vote suppression to the way in which it arbitrarily privileges certain voters. ${ }^{278}$

While winner-take-all's deficiencies can be readily enumerated, it is correspondingly difficult to find a principled defense of the system. To some extent, this is unsurprising, because winner-take-all became the prevailing system through a state-by-state search for local and partisan advantage, rather than a process of national discussion and compromise. Thus, winner-take-all allocation of votes cannot be said to be part of the electoral college's original design. Nor, for that matter, is it a product of the renewed consideration of voting and representation that occurred after the Civil War. ${ }^{279}$ Defenders of winner-take-all have, however, tended to obscure this point by lumping winner-take-all with other features of the electoral college, often suggesting that both are part of the Framers' wisdom. ${ }^{280}$ Thus, for example, Tara Ross describes the unified effects of the electoral college as one of many measures instituted by the Framers to "give minorities more influence than they would have in a simple democracy." 281 In a foreword to Ross's book, George Will decries efforts to change any aspect of the electoral college, including winner-take-all, arguing that reformers "appeal to single-mindedhence simple-minded - majoritarians" who fail to take the "wiser path" of "study[ing] the logic and rationale that prompted the Framers to

277. See Note, Rethinking the Electoral College Debate: The Framers, Federalism, and One Person, One Vote, 114 Harv. L. REv. 2526, 2533 (2001) [hereinafter The Electoral College Debate] (observing that "the effects of the winner-take-all feature generally dominate all other effects, and though it may sometimes benefit large states, its impact in any given election will be unpredictable because small shifts of support among large states can easily change the electoral outcome"). As previously discussed, other electoral college mechanisms may have had a greater influence historically; for example, when states restricted ballot access by blacks or women, the allocation of electoral votes based on population had a more significant effect. See supra Part I.B.

278. See supra Part II.A.1.

279. See supra Part I.B.

280. See The Electoral College Debate, supra note 277, at 2541 ("Many articles in the popular press have, in the wake of the 2000 election, sung the Framers' praises and hailed their foresight in designing the Constitution to protect small states and our federal structure from 'simple-minded majoritarianism.'”).

281. Ross, supra note 9 , at 40 . 
avoid a national popular election . . .." 282 Likewise, Alexander Bickel has argued that the electoral college formed part of the Framers' efforts "to approximate the true representation of the people by providing many different ways of counting heads," thus avoiding "a simple and invariable majoritarianism [that] has never been what we have meant by democracy." 283

These defenses blur the distinction between the distinct mechanisms - the two-vote bonus, population-based electoral vote allocation, and winner-take-all voting-by which the electoral college may diverge from the popular result, and further ignores that the Framers' original design included independent voting by electors, ${ }^{284} \mathrm{a}$ feature that has long been absent from the electoral college process. Further, given that the emergence of winner-take-all was utterly unforeseen when the Constitution was drafted, defenders face a higher burden to show how this specific device is consistent with the Framers' goals - a difficult hurdle to meet. As this Article has argued repeatedly, the key feature of winner-take-all is the arbitrariness with which it distributes power and alters popular results. While one might argue that principles of federalism demand special solicitude for small states or that a notion of virtual representation mandates population-based vote allocation, no comparable structural principle explains why residents of, say, Florida and New Hampshire should have more sway over election outcomes than residents of California and Wyoming. ${ }^{285}$

To the extent winner-take-all has been defended on its own merits, many arguments in its favor are inadequately reasoned and unconvincing. Some defenders emphasize, for example, that the hurdle of winner-take-all can be overcome through wise allocation of campaign resources. ${ }^{286}$ But such arguments fail to explain why it is desirable to require candidates to overcome an essentially meaningless hurdle in the first place, nor how the country benefits from campaigns that focus narrowly on a small number of swing states. Other defenses are based on faulty assumptions, arguing that winner-takes-all benefits racial

282. Id. at xi.

283. BICKEL, supra note 158 , at 15 .

284. See supra note 99 and accompanying text.

285. For an account of the degree to which such disparities in voter power were present in the 2016 election, see Gelman, supra note 213.

286. See Althouse, supra note 7, at 1012; BEST, supra note 9, at 66 . 
minorities ${ }^{287}$ or rural voters ${ }^{288}$ when in fact it appears to do the opposite in both cases, ${ }^{289}$ or asserting that winner-take-all forces candidates to appeal to many states ${ }^{290}$ where the historical evidence suggests that, instead, it often offers disproportionate rewards to candidates with regional appeal. ${ }^{291}$

More general thoughts that the electoral college, presumably including winner-take-all, encourages "moderation" 292 and "national consensus" 293 while hindering the chances that "extremist factions" will come to power ${ }^{294}$ are speculation supported by little evidence, and ring almost comically hollow in the wake of the 2016 election, in which Donald Trump - surely one of the most divisive figures in U.S. historyowed both his primary ${ }^{295}$ and general election ${ }^{296}$ victories substantially to winner-take-all allocation. Indeed, one could easily engage in the counter-speculation that winner-take-all is most likely to enable the rise

287. See BEst, supra note 9, at 208 (arguing that the electoral college enhances the influence of "well-organized urban minorities"); BICKEL, supra note 158, at 13 (arguing that the electoral college gives more power to racial or ethnic minorities).

288. See Ross, supra note 9, at 81 (contending that the electoral college gives "[s]mall states, rural areas and sparsely populated regions" a "voice" that they would lack under direct election).

289. See supra notes 203 and 205 and accompanying text.

290. See Ross, supra note 9, at 79 (stating-incorrectly-that because of the electoral college, "[p]residential candidates . . . tour the nation, campaigning in all states").

291. See Longley \& PeIRCE, supra note 108, at 158-59 (arguing that thirdparty candidates with concentrated regional strength, such as Strom Thurmond or George Wallace, are benefited by winner-take-all).

292. See BEST, supra note 9 , at 98 .

293. See Kathryn Jean Lopez, Hillary Is Wrong: An Interview with Charles $R$. Kesler, NAT'L Rev. OnLine (Nov. 13, 2000), http://web.archive.org/web/ 20010120071025/httb://www.nationalreview.com/interrogatory/interrogato ry111300.shtml [https://perma.cc/BV92-BQPX].

294. See Ross, supra note 9 , at 98 .

295. See Silver, supra note 260 (explaining that Trump would have been unlikely to win the Republican nomination had delegates been awarded proportionately).

296. See Lessig, supra note 22 (presenting analysis suggesting that Trump would have lost the election under a fractional proportional allocation scheme). See also Derek T. Muller, Five Fictional Electoral College Outcomes from the 2016 Presidential Election, Excess OF Democracy (Feb. 24, 2017), https://excessofdemocracy.com/blog/2017/2/five-fictional-electoral-collegeoutcomes-from-the-2016-presidential-election [https://perma.cc/LQ72-8T3A] (re-analyzing the 2016 election results according to five different alternative vote allocation systems). 
of polarizing candidates. That is, if one assumes - as currently appears to be the case ${ }^{297}$ - that swing states are dominated by approximately equal numbers of unpersuadable partisans of each party, the candidate with the most passionate supporters may be most likely to have a small edge in turnout sufficient to win all the state's electoral votes. Thus, candidates may have an incentive to appeal strongly to a narrow, intensely opinionated group rather than try to win over a broader swath of centrist voters. ${ }^{298}$

As an additional argument, some have suggested that the disproportionate campaign resources expended on swing states ensures that voters in influential states will also be the best-informed or that candidates will be forced to tailor their appeals to reach voters in the middle. ${ }^{299}$ Both of these assumptions, however, are flawed. Little to no empirical evidence supports the idea that persuadable voters in swing states are more knowledgeable than others; indeed, most studies have suggested that undecided voters are generally more poorly informed..$^{300}$ Likewise, as more Americans have become hardened partisans, campaign strategy in swing states has evolved toward turning out alreadycommitted voters rather than persuading undecided ones. ${ }^{301}$ It is a mistake, therefore, to see swing states as moderate or centrist; rather,

297. See Peter Grier, The Number of Undecided Voters in the U.S. Won't Stop Shrinking, CHRISTIAN SCI. MONITOR (Jun. 29, 2015), http://www. businessinsider.com/the-number-of-undecided-voters-in-the-us-wont-stopshrinking-2015-6 [https://perma.cc/P4Q4-AWTL] (explaining that the number of undecided voters is declining, most nominally undecided voters tend to actually affiliate with one of the major parties, and as a result "big political campaigns are increasingly focusing on their own partisans, instead of trying to win over undecideds").

298. Writing in 2004, Paul Boudreaux conceived a scenario of this sort that bears more than a passing resemblance to the 2016 election. Boudreaux suggested that in the future, anxiety over gay marriage and Muslim cultural influence might lead to a "traditional American family values" party espousing "ethnic, religious, and cultural intolerance of those who do not fit the mold of the traditional Christian lifestyle." Boudreaux, supra note 222, at 234. Such a candidate, Boudreaux speculated, could win the electoral college through narrow pluralities in conservative states even while decisively losing the popular vote due to wide margins of defeat in blue states. $I d$. at 235 .

299. See Ross, supra note 9, at 79-80 (arguing that the electoral college provides incentives for candidates to build wide, national, non-ideological coalitions).

300. See, e.g, Palfrey \& Poole, supra note 215, at 530; Bawn et al., supra note 180 , at 9 .

301. See Grier, supra note 297; see also Ronald Brownstein \& Leah Askarinam, The Tipping Points of the 2016 Election, Atlantic (Oct. 25, 2016), https://www.theatlantic.com/politics/archive/2016/10/the-tipping-pointsof-the-2016-election/505238/ [https://perma.cc/R4GD-WTJY] (explaining in detail how swing states are increasingly driven by "stark demographic divides" that go hand in hand with partisan affiliation). 
they are simply states that happen, by virtue of geographical fortuity, to have approximately equal numbers of partisan Democrats and partisan Republicans, often inhabiting different areas of the state and feeling little affinity for each other. ${ }^{302}$ Even if it were true that voters in close states were slightly more moderate or more knowledgeable on average, it is unclear that this would justify giving such voters either the burden or the benefit of the wildly disproportionate power they now exercise. ${ }^{303}$

Some commentators have argued that winner-take-all simply does not matter a great deal because it has little effect on the outcome. Ann Althouse argues that races producing a popular-electoral split are generally close; in such elections, "all one really needs is a device to determine an outcome" and "the traditional method . . . should have the most power to bring stability and legitimacy." 304 Althouse notes, for example, that the popular-electoral split of 2000 did not bring about the crisis many commentators in the 1960s and 1970s had feared. ${ }^{305}$ Yet the public shrug at George W. Bush's popular vote defeat shows only that under a highly specific set of circumstances, including an extraordinarily close popular and electoral split as well as a Supreme Court battle that focused attention elsewhere, ${ }^{306}$ one particular fear articulated by past commentators proved to be overblown. It ignores the other ways, both subtle and not, in which winner-take-all has proved destabilizing by creating electoral margins that are a misleading signal of public support, by inviting fraud and voter suppression, and by encouraging candidates to adopt messages narrowly targeted to small constituencies in swing states.

A last-ditch version of the argument against changing winner-takeall rests on a defense of the electoral college more generally - in short, that the institution as a whole has provided stability and that to tamper with any piece of it would invite disruption. In discussing efforts to reform the electoral process in general, Alexander Bickel has cautioned that while "[t]here may be a time when societies can digest radical structural change .... We are not such a society. We do well to remain attached to institutions . . . ." ${ }^{307}$ Judith Best likewise argues that one

302. See Brownstein \& Askaranam, supra note 301.

303. As a popular tweet sardonically put it, "democracy is this cool system where you yell at people online for 6 months and then people in Ohio and Florida pick the president." Alboo (@bromanconsul), TwITTER (June 14, 2016, 1:00 AM), https://twitter.com/bromanconsul/status/742627660367429632?lang $=$ en [https://perma.cc/8FER-ESBZ].

304. See Althouse, supra note 7 , at 1013.

305. See id. at 1013-14.

306. Id. at 1011.

307. BICKEL, supra note 158 , at 3. 
of the principal advantages of the electoral college is that it "promises stability." 308 Defenders have argued more specifically that abolishing the electoral college may bring radical changes, such as the runaway growth of third parties, that are difficult to foresee or contain. ${ }^{309}$ A problem with these arguments, however, is that they generally address only a narrow question: whether the electoral college as a whole should be replaced by direct election of the president. Indeed, many electoral college defenses are less arguments for why all its features - particularly winner-take-all - are better than the alternatives than they are enumerations of the potential problems that direct election might pose. ${ }^{310}$ Yet the electoral college could at least in theory be reformed without eliminating all of its elements entirely, and alternatives other than direct election exist. Further, as previously noted, arguments that the electoral college promotes stability and moderate, mainstream candidates are substantially undermined by the results of the 2016 election. ${ }^{311}$

In the end, many defenses of winner-take-all have the uncomfortable appearance of an effort to come up with a post hoc rationalization of anomalous results. As one commentator noted of the 2000 election: "The problem is that no conceivable justification for the electoral college can simultaneously rationalize the actual result, in which Gore won the popular vote but lost the election, and the virtually identical scenario in which he wins the election but loses the popular vote." 312

308. See BEST, supra note 9, at 217.

309. See Ross, supra note 9, at 41 (arguing that the electoral college limits the growth of "extremist or unhealthy" third parties); BEST, supra note 9, at 99 (arguing that the electoral college is desirable because it "minimizes thirdparty strength"); BICKEL, supra note 158, at 22 (contending that, by suppressing third-party candidates, the electoral college helps "enable[] us to achieve a politics of coalition and accommodation rather than of ideological and charismatic fragmentation, governments that are moderate, and a regime that is stable").

310. Judith Best's defense of the electoral college, for example, is titled The Case Against Direct Election of the President. See BEST, supra note 9, at 216. Ross's book, which considers electoral college reforms other than direct election, is a partial exception, although many of Ross's pro-Electoral College arguments are primarily objections to direct election. See Ross, supra note 9 , at 149 .

311. See supra Part I.B.

312. See The Electoral College Debate, supra note 277, at 2541. As the author elaborated, "Why ... do we have an electoral college that says that Al Gore should lose the 2000 presidential election even though he won more votes? There may be good federalism-based reasons, but none of them survives empirical scrutiny. For example, perhaps the electoral college made a loser of $\mathrm{Al}$ Gore because he lost too many small states, and small states are important. Or perhaps his support was overly concentrated in New York and California, 
Perhaps the best way of evaluating winner-take-all is to compare it to the other counter-majoritarian features of the electoral college, which represent negotiated tradeoffs between constituencies and judgments about the wisdom of various approaches. At the Constitutional Convention, the two-vote bonus was a necessary part of securing the support of small states that worried their interests would be neglected in a system of direct presidential election. ${ }^{313}$ Likewise, population-based representation was an issue of acute concern at the Constitutional Convention; ${ }^{314}$ strikingly, even post-Civil War, Congress opted after extensive deliberation to continue a primarily population-based system, despite legislators' recognition of the injustice of the three-fifths clause and determination to prevent southern states from ever again gaining excess representation based on a disenfranchised black population. ${ }^{315}$ It is easy to see why states considered themselves to have such a strong stake in these decisions, which represented clear tradeoffs between state interests, as determined by clear, non-arbitrary characteristics of state populations.

None of this is to suggest that the compromises arrived at by the Constitutional Convention and the 39th Congress on these questions are exempt from criticism or that the judgments they represent cannot be revisited. The two-vote bonus, for example, has been criticized as anachronistic and unfair. ${ }^{316}$ Further, although the matter was certainly the subject of some debate at the Constitutional Convention, the ultimate outcome can be seen as a hasty, expedient resolution of what was regarded at the time - due to the likely election of George Washington under any system - as a secondary issue. ${ }^{317}$ Population-based state representation likewise can be assailed on many grounds, from its origins in the protection of slavery to the lack of incentive it provides to extend the franchise or increase turnout. Such arguments have considerable force, and help make the case for a switch to direct election,

where he accumulated 'wasted votes.' Or perhaps he was merely a 'regional' candidate. None of these reasons makes sense in the context of the 2000 election, however, because none explains the equally plausible scenario in which $\mathrm{Al}$ Gore wins the electoral vote. A shift of a mere 538 votes from any state that Gore won to Florida would have produced a Gore victory without his gaining a single vote." Id. at 2540. See also LONGLEY \& Braun, supra note 2 , at 22 (quoting political scientist John P. Roche describing the electoral college as a "jerry-rigged improvisation which has subsequently been endowed with a high theoretical content").

313. See Slonim, supra note 51, at 40.

314. See supra Part I.A.

315. See supra Part I.B.

316. The Electoral College Debate, supra note 277, at 2537-40.

317. See Aвbott \& Levine, supra note 6, at 11. 
which would eliminate in one stroke these other undemocratic features of the electoral college along with winner-take-all.

At the same time, however, a meaningful distinction should be drawn between the features of the electoral college that vary from direct popular election by design ${ }^{318}$ and winner-take-all, which has no such justification. An election in which a popular vote runner-up wins the electoral college vote through disproportionate popularity in small states represents the system, for better or worse, working as intended; the electoral college compromise was crafted precisely in order to give small states this sort of additional influence. ${ }^{319}$ By contrast, the award of a large state's entire slate of electoral votes to a candidate who has edged out a three-digit plurality in that state's vote is a purely fortuitous occurrence, reflecting no national debate about the desirability of such an outcome.

Further, leaving aside the lucky candidate and his supporters, the second result does not systematically benefit anyone in particular and so cannot be seen as a compromise among competing interests. By contrast, the electoral college's other counter-majoritarian features were expressly intended to confer an advantage on, or at least remove a disadvantage from, states with particular characteristics - respectively, a smaller-than-average population and a population with a smallerthan-average percentage of eligible voters. These preferences may or may not be desirable, but they are at least rational. Winner-take-all, on the other hand, to the extent it confers any advantage, does so on closely divided states. Yet relatively few states are battleground states - nine or ten in recent elections, ${ }^{320}$ a number that has been declining for decades ${ }^{321}$ - so such benefits are not widely distributed. ${ }^{322}$ Further, closely divided states are not a recognized constituency, and there is no particular reason why they should share common interests

318. See The Electoral College Debate, supra note 277, at 2533 (noting that the two-vote bonus distorts the popular vote but is a "direct product of the Framers' original constitutional design").

319. See id. at 2530 (arguing that, of the Framers' original justifications for the electoral college, only one "the desire to strike an appropriate balance between large-state and small-state representation in presidential selection"continues to be "valid and important").

320. See Leatherby \& Harris, supra note 199.

321. See $i d$. (arguing that voters' increasing polarization decreases the number of swing states); see also FAIRVoTE, The Shrinking Battleground: The 2008 Presidential Election and Beyond 1, http://archive.fairvote.org/media/nern/ Shrinking Battleground_Final.pdf [https://perma.cc/MPK9-KJ37] (last visited Oct. 8, 2017).

322. See KozA ET AL., supra note 3, at 441-45 (discussing the fact that in 2012, more than 90 percent of advertising dollars, field offices, and other campaign resources were concentrated in a handful of states). 
or receive special solicitude. The category of "swing states" is made all the more meaningless by its arbitrariness, as the states that are closely contested change from year to year. Some states have been closely fought in several elections; ${ }^{323}$ others have not been seriously contested for more than a century; ${ }^{324}$ yet another, small group of states has moved back and forth between "swing" and "safe" categories. ${ }^{325}$ Additionally underscoring that "closeness" is not an immutable or terribly meaningful state characteristic, in many cases trivial changes in state boundaries would produce a different result. An interactive tool popular after the 2016 election demonstrated, for example, that Hillary Clinton would have won the electoral vote had just four counties been moved across state lines. ${ }^{326}$ Thus, winner-take-all does not just confer special power on certain states; it does so unpredictably and arbitrarily.

Even if we were somehow to regard "closeness" as a relevant quality deserving of special status, it is far from clear that the electoral college confers on swing states an unmitigated benefit. When the citizens of a state can arrive at a strong consensus on which presidential candidate they prefer, it is easy to see why they might wish for their state to have the maximum possible ability to translate that preference into influence over the national result. When a closely divided state is won by 115 or 537 votes, ${ }^{327}$ however, the award of the state's entire electoral slate to a single candidate disadvantages nearly as many state citizens as it advantages. ${ }^{328}$

323. See id. at 454 (noting that Pennsylvania has been a battleground state in several elections, although it was not in 2012).

324. See $i d$. at 453 ("The year 2012 is the 100th anniversary of the last time the popular-vote margin in Utah and Nebraska was less than 6\%.").

325. See id. at 454 ("After decades of voting solidly Republican in presidential elections, Virginia and North Carolina suddenly emerged as battleground states in 2008 ....").

326. See Christopher Ingraham, How the Electoral College Gerrymanders the Presidential Vote, Wash. Post: Wonkblog (Nov. 29, 2016), https:// www.washingtonpost.com/news/wonk/wp/2016/11/29/how-the-electoralcollege-gerrymanders-the-presidential-vote/?utm_term=.ab6fd4ee0ac4 [https: //perma.cc/B4RQ-XUHR].

327. These are, respectively, John F. Kennedy's Hawaii margin in 1960, and George W. Bush's in Florida in 2000. See Leip, supra note 62.

328. Of course, the argument can be made that swing state voters, win or lose, derive benefits other than sway over electoral outcomes; they receive disproportionate attention from candidates and may receive special solicitude from the president's party in designing legislation and bestowing funds. See, e.g., Nzelibe, supra note 191, at 1272 (noting the "rampant coddling" of swing states, which he criticizes as "parochialism"). These benefits are, however, difficult to defend on any principled grounds; it is hard to see why living in a closely divided state should entitle someone to additional disaster relief, for 


\section{The Practical Consequences of a Winner-Take-All Focus}

If we regard the winner-take-all feature of the electoral college as uniquely indefensible, what are the consequences?

To begin with, defenders of the electoral college should be challenged specifically to explain why the winner-take-all feature of the electoral college is better than alternatives. Defenders of winner-takeall electoral vote assignment have argued, for example, that the system has historically produced clear results, without the necessity of invoking the contingency feature for deciding elections in the House; ${ }^{329}$ they likewise contend that winner-take-all supports the two-party system because third parties have difficulty in garnering a meaningful number of electoral votes. ${ }^{330}$ Some have also argued that it promotes federalism for control of voting to be left to the states and for states to be seen as independent units in a presidential election. ${ }^{331}$ But even if one regards these as desirable goals, they do not specifically justify a winner-takeall system because there are many other ways of achieving them. For example, a system of proportional allocation like that used in Democratic primaries, in which a candidate is entitled to a share of a state's delegates only after exceeding a certain threshold of votes, ${ }^{332}$ might well be similarly effective in marginalizing third-party candidates and avoiding contested elections. Likewise, if the role of the House in resolving presidential contests is problematic, it could be replaced by another mechanism such as a runoff, a feature that has been included in many reform proposals. ${ }^{333}$ Finally, proportional allocation and bonus-vote plans-under which the national popular-vote victor would receive additional electoral votes ${ }^{334}$ - are similar to winner-takes-all in providing for state-focused elections rather than a single national one.

example. Moreover, as swing state status shifts frequently, a state cannot plan for or count on such benefits.

329. See BEST, supra note 9, at 210.

330. See id. at 90-91.

331. See Boudreaux, supra note 222, at 195-96 (describing this argument but critiquing it on grounds that "today's electoral systems serves no purpose of real federalism, under which states would exercise independent sovereignty").

332. KozA ET AL., supra note 3, at 130.

333. Another alternative is to allow a plurality electoral vote winner to become president, as an amendment proposed in 1950 to make allocation of electoral votes proportional would have done. See KOZA ET AL., supra note 3, at 139. By contrast, relying on winner-take-all to produce results that do not need House resolution is both risky - because it relies on past experience that may not continue to hold true - and unnecessary.

334. See KozA ET AL., supra note 3, at 141-42. 
At the same time, it may be helpful for opponents of the electoral college to acknowledge that some of the institution's undemocratic features both have more inherent legitimacy than winner-take-all andbecause they implicate fixed, identifiable state interests-may, in practice, face the stiffest resistance to change. The late-1960s efforts to institute direct election by constitutional amendment - the nearest the country has come since the Twelfth Amendment to electoral college abolition or serious reform - attracted persistent opposition from some small states, even as others supported the measure. ${ }^{335}$ It is notable that some small states persisted in their opposition notwithstanding evidence that large states are the primary electoral college beneficiaries. ${ }^{336}$ Similarly, representatives in the 39th Congress rejected voter-based representation in both Congress and the electoral college in favor of representation based on population, ${ }^{337}$ despite ample opportunity and incentives to opt for the former. While the enfranchisement of AfricanAmericans and women has made the issue less salient, states still vary substantially in the percentages of their citizens who can and do vote, meaning that certain states would lose power relative to the status quo in a system of direct election.

To be sure, attempts to reform winner-take-all may run into a similar perception that it will produce winners and losers: the current electoral map combined with the winner-take-all feature is currently perceived to confer an advantage on the Republican Party, and the 2000 and 2016 popular-electoral splits in the Republican candidate's favor are likely to cement this perception. ${ }^{338}$ At the same time, history suggests that both the facts of partisan benefit in the electoral college

335. See Longley \& Braun. supra note 2. at 176-77 (arguing that manv factors contributed to the amendment's downfall and small-state senators did not, for the most part, disproportionately oppose it). Nonetheless, those smallstate senators who did object to the proposal tended to cite potential loss of influence as a basis for their opposition. See id. at 164. More recently, electoral college defender Tara Ross has pointed out that, while small states might not be particularly influential in our current system, they would have even less sway under a direct election system. See Ross, supra note 9, at 82; see also Althouse, supra note 7, at 1006 (noting that while, in the 1960s and 70s, "[d]irect vote proponents disparaged as 'parochial' the criticisms based on which groups would win and which would lose," nonetheless "concerns of this kind may surely defeat reform").

336. See supra note 58 and accompanying text.

337. See supra notes 73-82 and accompanying text.

338. See Sean Darling-Hammond, The Electoral College Is Even More Biased Than You Think. But Democrats Can Beat It., NAtion (Jan. 17, 2017), https://www.thenation.com/article/the-electoral-college-is-even-more-biased -than-you-think-heres-how-democrats-can-beat-it/ [https://perma.cc/W7D P-8TJN] (arguing that "[s]tates identified as Republican strongholds, . . . are more over-represented, on average, than states of any other partisan bent"). 
and popular beliefs on the subject are likely to shift over time. In 1991, Abbott and Levine argued that the electoral college was, in fact, tilted in favor of Democrats, ${ }^{339}$ and the following year the substantial electoral victory of Bill Clinton-winner of just a 42 percent plurality in the popular vote - seemed to bear this out. ${ }^{340}$ Following the 2012 election, when Barack Obama won both the popular and electoral vote by comfortable margins, the idea that Democrats had an inherent electoral college advantage, even a "stranglehold, ${ }^{341}$ was widely circulated ${ }^{342}$ including by the man-Donald Trump-who would go on in the next election to benefit from the electoral college's winner-take-all feature. ${ }^{343}$ The future election of a Democratic president by a larger electoral than popular margin may again shift perceptions about which party enjoys an electoral college advantage, and may thus be an opportune moment to press for reform.

\section{Reform Proposals and Winner-Take-All}

Centralizing the goal of eliminating winner-take-all also has implications for the sort of alternatives that reformers should embrace. Advocates of electoral college reform should, for example, avoid solutions - such as allocating electoral votes based on congressional district - that would simply replicate the winner-take-all problem on a smaller scale. ${ }^{344}$ At the same time, reformers should arguably be open to proposals that preserve some current features of the electoral college while eliminating winner-takes-all. This is not to suggest that reformers should abandon the hope of direct election, which may well be both the best and the most feasible alternative proposal to the current system.

339. See Aвbоtт \& Levine, supra note 6, at 146-49.

340. See Victor Williams \& Alison M. Macdonald, Rethinking Article II, Section 1 and Its Twelfth Amendment Restatement: Challenging Our Nation's Malapportioned, Undemocratic Presidential Election Systems, 77 MARQ. L. REV. 201, 227-29 (1994) (arguing that "[t]he unit/winner-take-all method of casting electoral college votes that predominates in the states created the appearance of a clear mandate for the victor, Bill Clinton" despite his lackluster performance in the popular vote).

341. See Chris Cillizza, Democrats' Stranglehold on the Electoral College, in 1 GIF, Wash. Post (June 10, 2014), https://www.washingtonpost.com/ news/thefix/wp/2014/06/10/democrats-strangehold-on-the-electoral-collegein-1-gif/?utm_term=.5b71bbd47a32 [https://perma.cc/RC8Y-BKV6].

342. See, e.g., Chris Cillizza, In 2016 Race, an Electoral College Edge for Democrats, WAsh. Post (Mar. 15, 2015), https://www.washingtonpost. com/politics/in-2016-race-an-electoral-college-edge-for-democrats/2015/03/ 15/855f2792-cb3c-11e4-a2a7-9517a3a70506_story.html?utm_term=.8aaf4f9 741a3 [https://perma.cc/J7WT-UB96].

343. See Kessler, supra note 5.

344. See Аввотт \& Levine, supra note 6, at 127. 
At the same time, it is not necessarily justifiable to dismiss alternatives such as proportional allocation, as some reform leaders have, as "mak[ing] a bad system even worse." 345

\section{Direct Election: Proposals and Historical Experience}

Direct popular election is, for fairly obvious reasons, ${ }^{346}$ an intuitively appealing alternative that has long been the favored choice of electoral college reformers. It is the only plan that is the subject of a current, ongoing legislative effort in the form of the National Popular Vote Compact. ${ }^{347}$ Further, it is the electoral college alternative that has come closest to fruition. In the late 1960s, Congress came close to passing a constitutional amendment that would have abolished the electoral college and replaced it with a direct election system under which a runoff would be held if no candidate reached 40 percent of the vote. ${ }^{348}$

To be sure, even from the start, the plan-which passed the House as Joint Resolution $681^{349}$ — was not entirely without controversy. Initially, President Nixon, while supporting the overall concept of reform, preferred a plan to divide electoral votes proportionately, ${ }^{350}$ and legislators quibbled over whether a 50 percent runoff cutoff might be preferable before finally voting to reject an amendment to change the 40 percent rule. ${ }^{351}$ Ultimately, however, the House voted overwhelmingly338 to 70 - and on a bipartisan basis to pass the plan, with Democrats supporting it 184-44 and Republicans 154-26. ${ }^{352}$ Representatives of both

345. See KozA ET AL., supra note 3, at 680. Elsewhere, however, Koza et al. concede that a fractional proportional approach would be preferable to winner-take-all. See $i d$. at 139 (acknowledging that the fractional proportional approach would "improve upon the current situation" by making more votes "politically relevant").

346. Direct election would, of course, completely eliminate the winner-take-all problem as well as the other undemocratic aspects of the electoral college. Further, it is a simple, readily comprehensible reform.

347. KozA ET AL., supra note 3, at 258.

348. See Longley \& Braun, supra note 2, at 137-38.

349. Id. at 153 .

350. See id. at 142. In addition, John Mitchell, then U.S. Attorney General, testified-though, critics carped, with little evidence - that greater state support existed for the proportional plan. See id. at 145-46 (quoting Mitchell's testimony).

351. See id. at 150-51 (explaining that amendment was initially passed and then defeated on a subsequent teller vote).

352. Id. at 152 . 
the largest and the smallest states likewise both voted in favor of the resolution. ${ }^{353}$

The House's passage of the joint resolution was hailed in the media and proved popular with the public; further, it ultimately received the backing - albeit somewhat lukewarm - of President Nixon, despite his earlier preference for a proportional system. ${ }^{354}$ A survey of state legislative leaders and governors found that, while substantial support existed, the numbers were still a few short of the thirty-eight that would ultimately be needed for ratification. ${ }^{355}$ Meanwhile, procedural delays in the Senate resulted in some loss of momentum. ${ }^{356}$ By the time the bill was finally voted out of committee in $1970,{ }^{357}$ the opposition had gained force, ${ }^{358}$ and it began to look doubtful that proponents could muster the needed two-thirds. ${ }^{359}$ The bill faced a variety of obstacles: the stillhalfhearted support of the president, ${ }^{360}$ continued worries about the runoff provision, ${ }^{361}$ doubts by small-state and conservative senators, ${ }^{362}$ and - most crucially-opposition by southerners, who worried that national elections would weaken state power and perhaps also increase black turnout or stifle regional third-party candidates such as George Wallace. ${ }^{363}$ Eventually, these southern senators led a successful, though controversial, filibuster and killed the bill. ${ }^{364}$ Notably, cloture votes showed little variation based on state size-though the largest ten states were the most supportive of bill ${ }^{365}$ _ but significant differences based on region; large majorities of senators from all regions voted for cloture except for less than one quarter of southern senators and less

353. See id. at 153. There were some ominous sectional differences, however, with about half of Southern Democrats opposed to the plan. Id. at 152.

354. See $i d$. at 156 .

355. Id. at 157 .

356. See id. at 158-60.

357. See id. at 160 .

358. See id. at 165 .

359. See id. (noting that support was always at least seven votes short of the minimum needed).

360. See id. at 163 (observing that Nixon appeared to respond to events rather than exercise leadership).

361. See $i d$. at 164 .

362. See id. at 166.

363. Id. at 166.

364. See id. at 169-174.

365. See id. at 175. 
than half from mountain states. ${ }^{366}$ Ideology also appears to have played a role, with more liberal legislators in both the House ${ }^{367}$ and Senate ${ }^{368}$ being more likely to have supported reform.

The National Popular Vote Compact, conceived in the wake of the 2000 electoral-popular split, ${ }^{369}$ takes a different approach to achieving a similar result. Based on an idea initially developed by law professors Robert W. Bennett, Akhil Reed Amar, and Vikram David Amar, ${ }^{370}$ the plan takes advantages of states' constitutional power to determine how their electors should be appointed. It provides that, at such time in the future when states "cumulatively possessing a majority of the electoral votes shall have enacted this agreement in substantially the same form," the signatory states will be bound to appoint the electoral slate pledged to the national popular vote winner. ${ }^{371}$ At the time of writing, the plan had been enacted in eleven states with a total of 165 electoral votes, meaning that it must be passed in only enough additional states to constitute another 105 votes before it can become law. ${ }^{372}$

While in the abstract this sounds like a potentially surmountable hurdle, the pace of enactments has slowed considerably. The last state to enact the compact did so in 2014, and there is a clear partisan pattern to the enactments; all states that have signed on to the compact so far have also voted for the Democratic candidate in the last several presidential elections. ${ }^{373}$ While supporters initially hoped that enough states would agree to the compact for it to take effect in 2012, this ambition obviously did not come to pass. ${ }^{374}$ Numerous criticisms have been made of the plan, including its lack of a recount mechanism and the overall undesirability of effecting change to federal elections on a state-by-

366. See id. at 176 .

367. See $i d$. at 155 .

368. See id. at 177 .

369. KOZA ET AL., supra note 3, at 279.

370. See id. at 281-83.

371. Id. at $258-59$.

372. Status of National Popular Vote Bill in Each State, Nat'L Popular Vote, http://www.nationalpopularvote.com/state-status [https://perma.cc/ZQT 4-ECMW]. The plan has been enacted in California, the District of Columbia, Hawaii, Illinois, Massachusetts, Maryland, New Jersey, New York, Rhode Island, Vermont, and Washington. The bill has passed one legislative chamber in a number of other states; it has been introduced in all fifty states. Id.

373. See $i d$. (identifying the states that passed the proposal); Leip, supra note 62 (identifying states that voted for the Democratic candidate in the most recent presidential election).

374. See Williams, supra note 109, at 176. 
state, sub-constitutional level. ${ }^{375}$ Some commentators have suggested in addition that the plan may be constitutionally infirm under the Compact Clause. ${ }^{376}$

The National Popular Vote Compact is a creative and commendable approach to a difficult problem, and its historical moment may yet come. At the same time, supporters should not underestimate the magnitude of the change it proposes or the novelty of the mechanism it uses to effect such change. In any case, there is room both to consider alternative reform proposals and to contemplate what sort of arguments might win the compact additional support.

\section{Alternatives to Direct Election Proposals}

As the previous Section detailed, direct election has long been the preferred option for most reformers. However, it is important to note that the mechanism by which direct election eliminates winner-take-all is by abolishing - by definition - the features of the electoral college that cause it to differ from the national popular vote. There is, of course, much to be said for abandoning these features, and on balance it is likely the right thing to do. But even fervent advocates of direct election should take into account the arguments - both pragmatic and philosophical - for retaining these features, which are significantly stronger than the arguments in favor of winner-take-all. One way of acknowledging these arguments is to seriously entertain alternatives for electoral college reform.

Historically, electoral college reform proposals other than direct election have tended to fall within a few major categories. Some efforts have been directed at removing the possibility of faithless electors ${ }^{377}$ a reasonable cause but today a largely irrelevant one. ${ }^{378}$ Another common variety of proposal has been to award electoral votes by congressional district with the "constant two" going to the state winner, ${ }^{379}$ the plan currently used in Nebraska and Maine. ${ }^{380}$ This version of the electoral college, essentially a more fine-grained version of

375. See id. at 179-80. But see Amar, supra note 135, at 252-53 (proposing that, if the required number of states were to enact the compact, Congress could enact supplemental rules to address such problems).

376. See, e.g., Derek T. Muller, The Compact Clause and the National Popular Vote Interstate Compact, 6 EleCtion L.J. 372 (2008).

377. See Longley \& Braun, supra note 2, at 43-49 ("[T]he automatic plan would eliminate the office of elector while . . retaining all other aspects of the existing electoral college's allocation and counting of votes.").

378. In other words, the possibility that faithless electors will sway an election is today vanishingly unlikely. See supra note 11 and accompanying text.

379. Longley \& Braun, supra note 2 , at 57.

380. See id. at 99. 
the current one, has been described as creating a "series of miniature winner-take-all elections" in most of the country while resulting in no change at all to the smallest states, which would continue to award all three of their electoral votes to the winner regardless of margin. ${ }^{381}$ As a result, it is subject to most of the criticisms of the current winner-takeall system as well as some new ones, such as the notion that separation of powers would be "dangerously weakened" by using identical geographical boundaries for the presidency and for Congress. ${ }^{382}$

The first of these reforms, then, would leave the current winnertake-all system undisturbed, while the second would substitute a different and equally problematic form of winner-take-all. By contrast, two other reforms-proportional counting of electoral votes, provided fractional votes are allowed, ${ }^{383}$ and the award of bonus votes to the national popular vote victor - would eliminate or minimize the winnertake-all feature, while leaving the electoral college's other countermajoritarian elements substantially in place. As noted, there is at least a colorable case for taking such an approach.

The case for retaining the two-vote bonus is primarily, though perhaps not exclusively, a pragmatic one. Realistically, eliminating the bonus requires small states to give up some measure of power and relevance. This reality has fueled opposition to electoral college reform, ${ }^{384}$ including, to some degree, the Bayh-Celler plan described above - the electoral college reform proposal that has come closest to success in United States history. ${ }^{385}$ This sentiment may be puzzling, considering that some analysis suggests that the current configuration of the electoral college gives more influence in practice to large states. As others have argued, however, the extra votes small states wield in the electoral college may have symbolic significance that transcends such real-world mechanics. ${ }^{386}$ Further, even if the electoral college does

381. Id. at 57 .

382. See id. at $63-64$.

383. If electoral votes are rounded, winner-take-all effects would again appear in miniature, conferring arbitrary benefits on the candidate who happened to benefit from the rounding. See KozA ET AL., supra note 3, at 165-66.

384. See Aвbott \& Levine, supra note 6, at 142 (noting that senators from particularly large or small states have been disproportionately likely to oppose electoral college reform efforts).

385. While many small-state senators supported the plan and its primary opponents were from southern states, some small-state senators remained adamantly opposed. See Longley \& Braun, supra note 2, at 166 (noting that one source of opposition in the Senate was "some small-state senators convinced that direct vote would leave their states helpless in the hands of large populous states").

386. See Bickel, supra note 158, at 9 (observing that, while the electoral college disadvantages small states in many ways, it also has "symbolic value . . . for 
not particularly advantage most small states, they would be even worse off under a popular vote scheme. Wyoming, for example, represents about half of one percent of the electoral vote, but less than one fifth of one percent of the population of voters in presidential contests. ${ }^{387}$ As a solidly Republican small state, Wyoming gets virtually no attention in presidential contests, but it would have even less significance under a popular vote scheme. Further, small swing states, such as New Hampshire, would suffer a dramatic loss of relevance. ${ }^{388}$

While much harder to quantify, it seems plausible that the twovote bonus also plays a disproportionate role in the views of the minority of Americans who oppose abolishing the electoral college. ${ }^{389}$ As previously described, media coverage of the electoral-popular splits of 2000 and 2016 have frequently attributed the outcomes in these elections to the operation of the two-vote bonus-with some justification in 2000, though less so in 2016. Academic perspectives on the electoral college likewise have often focused on the bonus as its key mechanism of operation. ${ }^{390}$ This framing may contribute to the belief that the Electoral College gives the Republican Party a structural advantage, even though, in recent elections, the two-vote bonus has benefited Democrats and Republicans with about the same frequency. ${ }^{391}$ Further, insofar as the two-vote bonus is popularly considered to be the electoral college's most salient feature, it may invest the electoral college with an unwarranted legitimacy. The Great Compromise between large and

the small states, since the electoral college, on its face, confirms the federal structure, and in some measure the equality, as in the Senate, of all states, large and small.").

387. Wyoming has three electoral votes out of a total of 538. In 2016, approximately 255,849 votes for president were cast in Wyoming out of 137,125,484 nationwide. Leip, supra note 62.

388. While small swing states like New Hampshire would also lose considerable influence under a system of proportional allocation, they would obviously lose somewhat less were they permitted to retain the two-vote bonus. Further, it might be argued that their contributions to the national total would more accurately reflect their citizens' preferences.

389. The majority of Americans have generally supported abolition of the electoral college, although the percentage declined in the immediate wake of the 2016 election. See Terence P. Jeffrey, Support for Abolishing Electoral College Hits Historic Low in Gallup Poll, CNSNEws (Dec. 6, 2016), http://www.cnsnews. $\mathrm{com} /$ news/article/terence-p-jeffrey/support-abolishing-electoral-college-hitshistoric-low-gallup-poll [https://perma.cc/QEM6-KTR4].

390. See, e.g., Williams, supra note 109, at 192-94 (defending the electoral college on the basis that its "deviation from population apportionment . . is justified in order to serve federalism," but discussing only the two-vote bonus as a source of such deviation).

391. See supra note 62 and accompanying text. 
small states in legislative representation was, for better or worse, an important precondition to agreement on a constitution. ${ }^{392}$ To the extent the electoral college is seen primarily as a device for protecting the interests of small states, it may be regarded - even if incorrectly - as embodying an equally significant compromise and one that likewise reflects the United States' founding principles.

As with the two-vote bonus, a system that includes populationbased allocation can be defended on various grounds. Some critiques of direct election have praised the population-based allocation of the electoral college as limiting states' abilities to game national results by "enfranchising or disenfranchising . . . a small set of [their] citizens" while also providing "virtual representation" to nonvoting populations. ${ }^{394}$ Further, as with removing the two-vote bonus, a shift from population-based representation to the de facto voter-based representtation of direct election would produce losers as well as winners among states, meaning that states with large populations of noncitizens or others who do not vote might be more likely to oppose it.

Thus, reformers should perhaps not dismiss out of hand methods other than direct election. For example, some proposals to allocate electoral votes proportionally may merit consideration. Such proposals would, of course, have to be carefully designed. In contrast to the stateby-state action envisioned under the National Popular Vote Compact, for example, proportional representation would need to be accomplished by constitutional amendment to be fair and effective; indeed, attempts to advance the issue at the state level could be exploited dangerously for partisan advantage. ${ }^{395}$ Further, to avoid the need for arbitrary rounding, such a system would need to provide a mechanism for translating fractional percentage points into electoral votes, either by allowing fractional votes to be cast or by massively increasing the number of electors allotted per state. Finally, because many first-place candidates under such a system would be likely to attain only a plurality of electoral votes, ${ }^{396}$ the Twelfth Amendment provisions calling

392. See supra Section I.A.

393. See Muller, supra note 93, at 1241 (noting that such a move has the potential to "dramatically affect national elections").

394. See id. at 1243 ("[T]he Electoral College was founded upon a kind of republican vision of virtual representation in which a number of residents (including women, children, aliens, non-property owners, and, in part, slaves) would be included in a state's population tally for the allocation of electoral votes (and for that state's representation in the House of Representatives).").

395. See supra note 273 and accompanying text.

396. In the 2000 election, for example, it is likely that neither candidate would have won a majority of electoral votes had a proportional system been used. See supra note 137 and accompanying text. 
for such elections to be resolved by the House would likely have to be changed. This could be accomplished by lowering the required threshold for victory to 40 percent, awarding electors only to candidates who exceeded a vote percentage - such as the 15 percent used in Democratic primaries $^{397}$ - or providing for runoff elections if no candidate achieved a majority.

The need for such fixes would certainly create a system more complex than choosing a president by national popular vote, but one no more complex than the present method - and that would have some advantages. It would keep the states the primary administrators of the voting process, allowing them to set rules regarding eligibility and voting methods. Depending on its design, it could preserve the electoral college's ceremonial role in U.S. public life, allowing for the familiar ritual of electors meeting in state capitols to cast their votes. ${ }^{398}$ Most important, however, it would target the winner-take-all problem while potentially allowing the other electoral college features to be preserved. Electoral votes would continue to be population-based, and a proportional scheme would work equally well whether or not small states are allotted disproportionate representation ${ }^{399}$ —allowing for a frank debate on that issue that could take place separately from the discussion of the merits of the electoral college as a whole.

None of this is to deny serious problems with proportional schemes. Particularly if the two-vote bonus were retained, ${ }^{400}$ the potential for an

397. See supra note 246 and accompanying text. See also Lessig, supra note 22 (presenting results of proportional allocation of electoral votes in 2016 using a 5 percent threshold).

398. It has sometimes been assumed that proportional allocation that included fractional votes would eliminate the role of human electors, given that "since an actual elector, who is a real person, cannot give six-tenths of their vote to one person and four-tenths to another." See David S. Wagner, Note, The Forgotten Avenue of Reform: The Role of States in Electoral College Reform and the Use of Ballot Initiatives to Effect That Change, 25 REV. LiTiG. 575, 586 (2006). However, given the current role of electors as passive ratifiers of their state's results rather than independent agents exercising their own decision-making abilities, there seems no reason why a similarly ceremonial role for human electors in a fractional-vote system could not be devised if it were thought desirable. Of course, the practice of using human electors could easily be eliminated as well.

399. While most proposals for fractional proportional representation have included the two bonus votes, it is of course no more difficult to conceive a system in which states retain only their population-based electoral votes. This design would eliminate two of the Electoral College's countermajoritarian features - winner-take-all and the "constant two"-while continuing population-based representation.

400. Even disregarding the two-vote bonus, there are other ways in which it would be theoretically possible in such a system for the popular vote winner to lose the electoral college. The candidate could win disproportionately in high- 
electoral-popular split would remain-indeed, such a potential would be built into the system by design. Had a proportional system been in place, it may have prevented some popular-electoral splits including both 1876 and $1888,{ }^{401}$ but it might have created others, such as 1960, in which Nixon - who lost the popular vote by just over 100,000 votes, ${ }^{402}$ - would, under one analysis, have led by one-half of an electoral vote. $^{403}$ As previously noted, however, the popular-electoral splits created by a proportional scheme might be more justifiable, since they would reflect a deliberate decision to give greater weight to small states and states with a higher proportion of nonvoters. A proportional scheme could also be designed to minimize the likelihood of a runner-up president by, for example, including a runoff provision if no candidate won a majority.

Other issues are more technical. The proportional system would be complicated, requiring not only the oddity of fractional allocation of votes but additional measures to prevent plurality-winner elections from being decided by the House. ${ }^{404}$ Further, unless the basis under which electoral votes are initially awarded to states were also changed, electoral votes are currently rounded and thus represent an inexact method of population-based allocation. ${ }^{405}$ It has also been observed that, because electoral vote allocations are based on past censuses, they do not accurately reflect population totals at the time of voting. ${ }^{406}$ None-

turnout states, thus accumulating many additional votes while still being subject to those states' electoral-vote caps. In a close election, arbitrary variations due to rounding in each state's allocation of electoral votes could also produce or contribute to similar disparities.

401. See Twentieth Century Fund Task Force, supra note 125, at 46.

402. Leip, supra note 62 .

403. See Twentieth Century Fund Task Force, supra note 125, at 46.

404. Runoff provisions, for example, have proved controversial in congressional debate over electoral college alternatives. See supra note 351 and accompanying text.

405. For example, California's current allotment of fifty-three electoral votesdisregarding the two-vote bonus - represents 12.16 percent of the total pool of 436 population-based electoral votes. This is an approximate representation of California's 12.07 percent of the population in the 2010 census but not an exact one, and the difference could lead to slight distortions in the result even if electoral votes were awarded proportionately. QuickFacts: California, U.S. Census Bureau, https://www.census.gov/quickfacts/fact/table/CA,US/ PST040216 [https://perma.cc/5PHE-YZYL] (last visited Oct. 23, 2017). Changing the system by which states are initially allocated popular votes is of course possible, but would further complicate an already somewhat byzantine proposal and destroy the symmetry between electoral votes and congressional representation.

406. See Longley \& Braun, supra note 2, at 96. 
theless, these problems are not necessarily unresolvable. The Democratic primary experience with proportional delegate allocation, for example, suggests possible ways a proportional system could be successfully designed, and rounding issues are likely to be minor enough to be inconsequential in the vast majority of elections. ${ }^{407}$

A more indirect way of diluting the impact of winner-take-all is the so-called "national bonus plan"-a 1978 proposal by the think tanksponsored Task Force on Reform of the Presidential Election Process whose members included Arthur Schlesinger Jr., Jeane Kirkpatrick, and Patrick Caddell, among many other notable figures. ${ }^{408}$ Under this plan, the existing 538 electoral votes would be allocated as usual, but an additional 102 votes - two for each state plus the District of Columbia-would be allocated to the popular vote winner. ${ }^{409}$ The national bonus plan attracted little public or congressional support at the time it was introduced - it was a compromise that pleased no one, and even one of the task force members, Neil R. Peirce, regarded it as inferior to direct election. ${ }^{410}$ Nonetheless, a few commentators have urged renewed consideration of the plan in light of the popular-electoral splits of 2000 and $2016,{ }^{411}$ and the plan, despite the scant attention it received when proposed, has much to recommend it.

The national bonus plan clearly does not alter winner-take-all directly, ${ }^{412}$ and some might regard it as adding another complication to what one commentator has described as the "Rube Goldberg contrap-

407. For example, while California's share of the population does differ from its share of the electoral vote, the difference is relatively trivial-less than a tenth of a percentage point. See supra note 405.

408. See Abbott \& Levine, supra note 6, at 130; Twentieth Century Fund TASK ForCE, supra note 125 at 5.

409. Аввотт \& Levine, supra note 6 , at 130.

410. See Twentieth Century Fund TAsk Force, supra note 125, at 15 for Peirce's "partial dissent" praising the national bonus plan as "an innovative, commendable proposal that might well break the longstanding logjam on electoral college reform" but "dissent[ing] . . . from the Task Force's suggestion that the national bonus plan would be preferable to direct election."

411. See Chad Bickley, Electoral College: Keep, Reform, Replace?, Detroit Free Press (Nov. 18, 2016), http://www.freep.com/story/opinion/ contributors/2016/11/18/electoral-college-keep-reform-replace/94068566/ [https://perma.cc/E4VF-XXUD]; see also Arthur Schlesinger Jr., Bolster the Old System with Bonuses, L.A. Times (Dec. 17, 2000), http://articles. latimes.com/2000/dec/17/opinion/op-1069 [https://perma.cc/9AQP-FUT2].

412. Indeed, in some respects it adds to it, by creating a national pool of winnertake-all votes available to a candidate who wins the popular vote by even a minuscule margin. 
tion" $" 13$ that is the electoral college. Nonetheless, it would substantially dilute the more pernicious effects of state-by-state winner-take-all, making it unlikely that a small-margin win in even the largest few swing states would be decisive and thus lessening incentives to pander, cheat, or suppress in order to gain small numbers of votes. By making swingstate votes less likely to be individually decisive, it would also lessen the vast disparities in voting power between members of different states, while preserving the symbolic bonus given to small-state residents. Further, although it would not completely eliminate the possibility of popular-electoral splits, ${ }^{414}$ it would render such splits exceedingly improbable. ${ }^{415}$ Notably, the bonus plan would have resulted in the election of the popular-vote winner in all historical popularelectoral splits, including the election of $2016 .{ }^{416}$ At the same time, the bonus plan's retention of the electoral college's basic structure might appeal to those who fear the unforeseen consequences of more radical change, and it would mitigate what some detractors have seen as the undesirable pure majoritarianism of direct election by forcing candidates to strike a balance between campaigning in high-population areas and appealing to a coalition of states with attainable electoral votes. Finally, in contrast to proportional plans, the bonus-vote idea is fairly straightforward to grasp and would require fewer potentially divisive choices about how it should be structured. At the time the plan was proposed, task force member Neil R. Peirce-while continuing to believe that direct election was overall the preferable choice - nonetheless acknowledged both that the bonus plan was more politically feasible to enact and that it would be "infinitely preferable" to no change at all. ${ }^{417}$

Some may come away from the preceding discussion, of course, still convinced that direct election is the superior option and one worthy of continued advocacy. Even if, however, reform advocates continue to advocate for direct election as the best alternative, concentrating their critiques on winner-take-all rather than other electoral college features may help win additional support for their plan. Despite the near-

413. See Garrett Epps, No, Electors in States Trump Won Should Not Vote for Clinton, AtLANTIC (Nov. 11, 2016), https://www.theatlantic.com/politics/ archive/2016/11/the-electoral-college-is-bad-subverting-it-now-is-bad-fordemocracy/507401/ [https://perma.cc/M6BP-DY6G].

414. See AbBott \& Levine, supra note 6, at 131 (noting that a small probability of such a split would remain in close elections).

415. See id.

416. All such splits involved electoral-vote margins less than 102. The highest electoral-vote margin of victory of a popular-vote loser was Donald Trump's 2016 margin of seventy-four. Not considering faithless electors, Trump won 306-232 based on the election night results. See Leip, supra note 62.

417. See Twentieth Century Fund Task Force, supra note 125, at 15. 
unanimity of academic opinion that the winner-take-all feature is the greatest contributor to the electoral college's undemocratic effects, ${ }^{418}$ the other elements of the electoral college often loom larger in popular and media commentary. In 2016, for example, the winner-take-all feature played the most significant role in the popular-electoral split, ${ }^{419}$ but many media accounts focused on other factors, attributing Clinton's electoral loss, for example, to "our odd electoral system [that] gives more weight to voters in small, rural, mostly white states" ${ }^{420}$ or to the "outsized clout" the electoral college gives to "heavily populated states" that suppress voting rights. ${ }^{421}$ While these are perfectly legitimate critiques of the electoral college, it is misleading to suggest that these electoral college attributes brought about the 2016 result or are likely to have the greatest effect in future elections. All electoral systems have advantages and disadvantages; emphasizing that the dominant feature of the electoral college is also its most pernicious and indefensible might help to put into perspective whatever difficulties may attend direct election.

\section{Using the Courts to Undermine Winner-Take-All}

As a final note, some commentators have explored the possibility of judicial challenges to winner-take-all. In the aftermath of the 2016 election, Lawrence Lessig wrote an article promoting the analysis of an Atlanta lawyer, Jerry L. Sims, who argued that state use of a winnertake-all system violates the Equal Protection Clause by "den[ying] the minority of voters within each state any representation whatsoever

418. See The Electoral College Debate, supra note 277 at 2533 (noting that "the effects of the winner-take-all feature generally dominate all other effects"); LONGLEY \& PEIRCE, supra note 108, at 156 ("[T]he importance of the winner-take-all feature overshadows all other distortions [of the popular vote.]"); Sterling, supra note 13, at 170 (explaining that "[i]n most of the close elections since the Civil War, however, the bonus votes provided no advantage. This is because, with bloc voting by states, a sufficiently large pivotal state can deliver enough votes to offset the net bonus votes available to the opposition."); BEST, supra note 9, at 17-18 (noting that reformers since the nineteenth century have objected to winner-take-all schemes and proposed district-based or proportional plans as an alternative); NEIL R. Peirce, People's President: The Electoral College in American History and the Direct-Vote Alternative 180 (1968) (noting nearly a half-century ago that Electoral College critics have considered winner-takeall to be the "chief evil" of the existing system).

419. See Cohn, supra note 48.

420. Jesse Berney, Donald Trump, Loser-in-Chief, Rolling Stone (Dec. 2, 2016), http://www.rollingstone.com/politics/features/donald-trump-loserin-chief-w453504 [https://perma.cc/B3FM-HYJZ].

421. See Stern, supra note 33. 
within the Electoral College." ${ }^{422}$ Even though such reasoning may be persuasive in the abstract, it is hard to imagine these lines of argument meeting with much judicial receptiveness. Because of the sheer length of time winner-take-all has been in place, casting doubt on its constitutionality would be massively disruptive. Further, the Supreme Court has already given at least some consideration to the issue. In 1969, the Court issued a per curiam affirmance of Williams v. Virginia State Board of Elections ${ }^{423}$ in which a district court rejected an equal protection challenge to use of the "general ticket"-another term for winner-take-all-in Virginia. The Court found that there was no "invidious" discrimination against voters for the losing candidate because, in a formal sense, everyone had the same opportunity to cast a ballot: "Every citizen is offered equal suffrage and no deprivation of the franchise is suffered by anyone." ${ }^{424}$ Notably, two federal district courts were asked in the wake of the 2016 election to consider suits raising similar issues, and declined to consider them on grounds that Williams precluded them from revisiting the questions at hand. ${ }^{425}$

Even if ineffective in court, however, the critiques of litigants should have persuasive force in pointing out the anomalous nature of winnertake-all in U.S. voting practices. As one commentator has pointed out, many of the defenses of winner-take-all would sound absurd if advanced in the context of an internal state election. ${ }^{426}$ Indeed, in Gray $v$. Sanders, ${ }^{427}$ the Supreme Court forcefully rejected an electoral collegelike system at the state level. The case involved Democratic primary elections in Georgia, in which counties were given a number of "unit

422. See Lessig, supra note 22. As Lessig noted, a constitutional critique of winner-take-all was also put forward in an article by Christopher Duquette and David Schultz, which argued "[o]n balance, winner-take-all systems for the allocation of presidential electors raise serious constitutional questions that the courts should address. . . . Some voters' decisions end up counting much more toward the outcome of a presidential election than votes of other people under winner-take-all." Christopher Duquette \& David Schultz, One Person, One Vote and the Constitutionality of the Winner-Take-All Allocation of Electoral College Votes, 2 TEnn. J.L. \& POL'y 453, 484 (2006).

423. 288 F. Supp. 622 (1968), aff'd per curiam 393 U.S. 320 (1969).

424. See $i d$. at 627 .

425. See Conant v. Brown, No. 3:16-cv-02290-HZ, 2017 WL 1170858, at *8 (D. Or. Apr. 25, 2017); Schweikert v. Herring, No. 3:16-CV-00072, 2016 WL 7046845, at *2 (W.D. Va. Dec. 2, 2016).

426. See The Electoral College Debate, supra note 277, at 2545 ("[I]it is difficult to imagine New York State deciding to use an electoral college system to elect its governor on the theory that candidates should spend more time campaigning in politically divided suburban counties than in Democratdominated New York City or Republican-dominated upstate regions.").

427. 372 U.S. 368 (1963). 
votes" equal to twice their number of state representatives. ${ }^{428}$ Unit votes were then awarded on a winner-take-all basis to the candidate attaining the highest number of popular votes in that county. ${ }^{429}$ This created severe inequities in representation: a unit vote in Georgia's least populous county represented 938 residents, while a unit vote in its most populous county represented 92,721 residents. ${ }^{430}$ In a $7-1$ opinion, the Court forcefully rejected this system as a violation of the Equal Protection Clause, asking rhetorically: "How . . . can one person be given twice or 10 times the voting power of another person in a statewide election merely because he lives in a rural area . . . ?"431 Interestingly, the Court appeared to recognize the similarities between Georgia's system and the electoral college, but dismissed the comparison as inapposite on the ground that the electoral college was "designed by men who did not want the election of the President to be left to the people" 132 - an odd argument given that winner-take-all systems in their current form were not anticipated by the Framers ${ }^{433}$ and do, in fact, leave the matter to the people in some sense by putting the choice of electors to popular vote.

There is some constitutional basis for distinguishing cases like Gray from challenges to states' use of winner-take-all rules in presidential elections, since Article II, $\S 1$ has been construed to invest states with plenary discretion to assign their electors as they see fit, including through appointment without a popular vote, a practice that would certainly be widely condemned as undemocratic if instituted today. ${ }^{434}$ Yet as a matter of logic, fairness, and policy, the winner-take-all system makes as little sense in presidential contests as it did in Gray. Opponents of winner-take-all in the electoral college can thus forcefully argue that, while states using winner-take-all may technically be acting within their constitutional discretion, such rules are nonetheless in a broader sense inconsistent with constitutional values.

428. Id. at $370-71$.

429. Id.

430. Id. at 371 .

431. Id. at 379 .

432. Id. at 376 n.8.

433. See supra note 99 and accompanying text.

434. See Bush v. Gore, 531 U.S. 98, 104 (2000) (emphasizing the wide scope states possess to determine how their electors are assigned and that they may return to appointment at any time); McPherson v. Blacker, 146 U.S. 1, 25 (1892) (rejecting challenge to Michigan scheme under which electors would be appointed by district on the basis that "the legislature possesses plenary authority to direct the manner of [elector] appointment"). 


\section{Conclusion}

The electoral college has at least three mechanisms - the two-vote bonus, population-based allocation, and winner-take-all award of each state's votes - that have the potential to produce results distinct from those that would be achieved by direct election. While all three can be subject to reasonable criticism, the winner-take-all mechanism stands out starkly as the most harmful and least defensible. In contrast to the first two features, winner-take-all evolved wholly haphazardly at the state rather than federal level and did so as a result of narrow partisan jockeying, not reasoned debate or compromise. Moreover, winner-takeall produces pernicious effects ranging from popular-electoral splits to wide divergences in voter power that have proved troublesome throughout history and continue to be so today. At the same time, defenses of winner-take-all as a specific practice, when divorced from support from the electoral college in general, are few and unconvincing. As a result, advocates for electoral college reform should make abolition of winnertake-all central to both their critiques of the current process and their evaluation of reform proposals. 